\title{
Universiteit
}

Leiden

The Netherlands

\section{Historical overview: Descriptive and comparative research on South American Indian languages}

Adelaar, W.F.H.; Campbell L., Grondona V.M.

\section{Citation}

Adelaar, W. F. H. (2012). Historical overview: Descriptive and comparative research on South American Indian languages. In G. V. M. Campbell L. (Ed.), The Indigenous languages of South America. A Comprehensive Guide. (pp. 1-57). Berlin; Boston: De Gruyter Mouton. doi:10.1515/9783110258035

Version: $\quad$ Not Applicable (or Unknown)

License: $\quad$ Leiden University Non-exclusive license

Downloaded from: https://hdl.handle.net/1887/70117

Note: To cite this publication please use the final published version (if applicable). 


\title{
Historical overview: Descriptive and comparative research on South American Indian languages
}

\author{
Willem F. H. Adelaar
}

\section{Introduction}

The extreme language diversity that was characteristic for South America must have been a challenge to native groups throughout the subcontinent, struggling to maintain commercial and political relations with each other. Due to the absence of phonetically based writing systems in pre-European times there is hardly any documentation about the way cross-linguistic communication was achieved. However, the outlines of a conscious linguistic policy can be assumed from the Incas' success in imposing their language upon a millenary multilingual society. Second language learning, often by users of typologically widely different languages, must have been an everyday concern to the subjects of the Inca empire. Sixteenth-century chroniclers often report in a matter-of-fact way on the ease and rapidity with which native Americans mastered the language of their conquerors, be it Quechua, Spanish or any other language. Apart from such cases of political necessity, there are indications that language played an essential role in many South American native societies and that it could be manipulated and modified in a deliberate way. The use of stylistic speech levels among the Cuna (Sherzer 1983) and of ceremonial discourse among the Mbya (Cadogan 1959; Clastres 1974), the Shuar (Gnerre 1986) and the Trio (Carlin 2004), the appreciation of rhetorical skill as a requisite for leadership among the Mapuche, the distinction of female and masculine speech among the Karaja (Rodrigues 2004) and the Chiquitano (Galeote 1993), the association of language choice and family lineage among the peoples of the Vaupes region (Sorensen 1967; Aikhenvald 2002), and the association of language choice and professional occupation in highland Bolivia (Howard 1995) appear to indicate an awareness of linguistic functionality not limited to daily communication alone. The existence of engineered professional languages, such as Callahuaya, based on the unification of elements from two or more languages (Stark 1972; Muysken 1997), or contact languages based on the same principle, such as the Ecuadorian Media Lengua (Muysken 1979), the unusual and complex borrowing relations that exist between Aymaran and Quechuan (Cerron-Palomino 2000: 298-337), or between Amuesha and a neighboring variety of Quechuan (Wise 1976, Adelaar 2006) all suggest a tradition of conscious and deliberate choices relating to language use. Finally, the extraordinary complexity and rigidity of the grammatical 
systems of many South American languages suggest the opposite of anything such as sloppiness or indifference towards linguistic matters.

\section{camp_001.pod 2}

\section{7-10-06 13:07:39 -mu- mu}

\section{Willem F. H. Adelaar}

\section{Spanish and Portuguese colonial grammars and lexicography}

In the second decade of the 16th century, Francisco Pizarro, a native of Extremadura in Spain, set out from Panama with a handful of adventurers in search of the legendary riches of the Inca Empire. Remembering the tiresome linguistic experiences of his predecessors in Mexico, Central America and the Antilles, Pizarro made it a priority to be able to count on reliable interpreters before starting his conquest. For that purpose, several young men were abducted by the Spaniards roaming the coast of present-day Colombia. They were trained as lenguas or lenguaraces, interpreters able to speak and understand both Spanish and the Inca language. According to the chronicler Juan de Betanzos ([1551] 1987: 284-285), one of these interpreters was to play a sinister role during Inca Atahualpa's captivity and the process leading to his execution in 1533. This event illustrates the position of manipulative power that befell individuals able to bridge the communication gap in the early days of Spanish-Indian contact.

Right from the beginning, communication with the indigenous Americans and their innumerable languages became a major challenge to the conquerors and the colonial rulers that succeeded them. In order to effectively achieve the integration of native peoples within the colonial society and in order to spread Christianity among them, a common basis of understanding was needed. No one expected that a majority of the multilingual indigenous population would adopt the language of the conquerors soon, nor that they would feel inclined to do so. Furthermore, at the beginning of the colonial period, Spanish speakers were thinly spread and few in number in the South American domains, even though a migratory current of adventurers from previously conquered territories in Central America and the Caribbean was rapidly gaining importance.

In these circumstances it was logical to look at the indigenous languages as a means to administrate the native peoples and propagate the Christian faith among them. Although some religious authorities argued that it was impossible to explain and discuss the essence of Roman Catholicism in a native American language, others found use of these languages essential for precisely that purpose. In 1596 
King Philip II of Spain rejected a proposal made by the Council of the Indies (Conse jo de Indias) for the forceful imposition of Spanish upon the indigenous population of the American territories. Instead, he ordered that the indigenous languages were to be used for the propagation of the Christian faith, and that priests engaged in missionary activity had to be fluent in the languages of the groups with which they intended to work (Zavala [1977: 38] cited in Rivarola [1990: 134]). From then on, knowledge of native languages became an obligatory component of the career descriptions of priests and members of religious congregations seeking employment in missionary activity and in the administration of the faith to indigenous peoples. This privileged status of the indigenous languages lasted until the second half of the 18th century, when the rulers of the Bourbon dynasty sought to

\section{camp_001.pod 3}

07-10-06 13:07:39 -mu- mu

Historical overview 3

impose Castilian as the only language throughout Spain's American domains (Triana y Antorveza 1987: 505-511; cf. Ostler 2005: 373-374).

Notwithstanding the ongoing discussion about the suitability of American Indian languages for the transmission of religious matters, efforts to study and codify the Inca language started soon after the end of the devastating civil wars that hit the newly conquered empire during the first years of Spanish occupation. The Spanish rulers were in the fortunate position that the previous Inca administration had favored the use of a single language, a variety of Quechuan initially referred to as 'the general language of the Inca' (lengua general del Ynga). The name Quechua itself was probably not used until the second half of the 16th century (CerronPalomino 1987: 32). Since the lengua general was widely used and understood, the Spaniards paid little attention to the multitude of local languages (lenguas particulares) that coexisted with the general Inca language at the time of their arrival. Only the most prestigious varieties of the Quechuan language group were taken into consideration, whereas the numerous Quechuan varieties of mainly local relevance were usually referred to as 'corrupt' versions of the Inca language. Occasionally, a divergent group of Quechuan varieties was treated as a separate language, as was the case of the central Peruvian Quechua I dialect group referred to as 'the Chinchaisuyo language' (lengua chinchaisuyo) in the wordlist by Figueredo ([1700] 1964). In the second half of the 16th century, the still widely spoken 
Aymara language also became an object of study, but the full extent of the linguistic diversity that once existed in the central Andean region remained largely unnoticed. By contrast, indigenous languages spoken in areas beyond the borders of the former Inca Empire, where Quechua was not the obvious lingua franca, were often painstakingly documented.

As might be expected, the study of the indigenous languages of the Spanish colonial domain lay entirely in the hands of missionaries and members of religious congregations. The first published description of a Quechuan language, consisting of a grammar and a dictionary, was authored by a Dominican and defender of the Indian cause, Domingo de Santo Tomas ([1560] 1994a, [1560] 1994b). His work represents the extinct variety originally spoken near Lima on the central Peruvian coast, with an admixture of elements traceable to the Quechuan varieties of the interior of central Peru. Santo Tomas' description is revealing because it reflects a Quechuan language as it was used at a local level and because it contains features no longer viable in most of the modern varieties, such as a rather unexpected prosodic system. Soon after, in the context of the reforms initiated during the viceroyship of Francisco de Toledo (1569-1581), the Third Council of Lima (Tercer Concilio Limense) initiated a project of normalization that sought to unify the numerous existent varieties of Quechuan. A committee of language specialists, some of them native speakers themselves, set out to establish a new norm for Quechua, by combining elements of its most important varieties and by eliminating some of the phonological complications, for instance, the distinction of glottalizCamp_

\section{1.pod 4}

\section{7-10-06 13:07:39 -mu- mu}

4 Willem F. H. Adelaar

ation and aspiration and the contrast between velar and uvular stops (Itier 1991: 70;

Mannheim 1991: 142). The new linguistic standard, which is exemplified by the religious instructions collected in the Doctrina Christiana y catecismo para instruccion de los indios (Ricardo [1584] 1985), remained in use as a written medium among indigenous elites for a couple of decades (Itier 1991). A case of a language that can only be studied today through the analysis of a religious text is Puquina. In the second half of the 16th century, Puquina was still counted as one of the 'general languages' ( lenguas generales) of Peru. Nevertheless, it probably became extinct in the early 19th century. The multilingual Rituale 
seu Manuale Peruanum of Geronimo de Ore (1607), although quite unsatisfactory

as a language source, contains the only available information on the Puquina language.

As long as no other sources are discovered, our knowledge of this language will remain limited and uncertain.

The arrival in the New World of members of the Jesuit order, established in 1569 by Saint Ignatius of Loyola, initiated a period of great and largely systematic activity in the field of language documentation. One of the first Jesuit language specialists in South America was Alonso de Barzana (or Barcena) (1528-1598). He wrote a number of grammatical descriptions, several of which were lost. Among the lost works were grammars of the extinct Diaguita and Tonocote languages, once spoken in what is now northwestern Argentina. The first decade of the 17th century brought some of the most brilliant descriptions of South American languages (all by Jesuits) in the entire colonial period. Diego Gonzalez Holguin ([1607] 1842, [1608] 1989) produced a grammar and a monumental dictionary of the then Cuzco variety of Quechuan. Ludovico Bertonio (1603, [1603] 1879, [1612] 1984), an Italian Jesuit, wrote two grammars and a dictionary of the Aymara language as it was spoken on the southern banks of Lake Titicaca. Luis de Valdivia ([1606] 1887) documented the Araucanian language (today's Mapudungun) of Chile and also provided grammatical studies of the extinct Allentiac and Millcayac languages, which were spoken in the area of Mendoza, San Juan and San Luis in present-day Argentina (Valdivia [1607] 1894; Marquez Miranda 1943). All three authors still cause modern readers to admire them, Holguin for his extensive lexicography, Bertonio for his keen sociolinguistic observations, and Valdivia for his phonetic accuracy and his eloquent discussion of novel linguistic phenomena such as noun incorporation.

A few decades later, the Jesuit grammar tradition developed in Peru was continued in the eastern lowlands with the work of Antonio Ruiz de Montoya on classical Guarani. Montoya published a Guarani-Spanish dictionary (Tesoro de la lengua guarani [Montoya (1639) 1876]) and a grammar with a Spanish-Guarani vocabulary (Montoya [1640] 1994). The Tesoro 'thesaurus' contains a wealth of semantic and ethnographic information helpful for understanding the transformation of the language during the Jesuit regime in the Paraguayan missions. Montoya's work complements that of another Spanish Jesuit, Joseph de Anchieta camp_001.pod 5 
07-10-06 13:07:39 -mu- mu

Historical overview 5

([1595] 1946), who wrote a grammar in Portuguese of the Tupinamba (Tupi) language

spoken along the Brazilian coast and on the lower course of the Amazon

River. Guarani and Tupinamba were closely related languages with a vast geographical distribution and with numerous speakers. The former has maintained its viability in several modern forms (Paraguayan Guarani, Mbya, Nhandeva, etc.), whereas the latter is now partly reflected in Nheengatu or Yeral, a lingua franca spoken in Brazil on the upper Rio Negro (to a lesser extent also on the upper Amazon) with extensions into Colombia and Venezuela.

The Chibcha or Muisca language of the eastern highlands around Bogota in Nueva Granada (today Colombia) also benefited from the attention of Spanish grammarians. No less than three grammars of this language have been preserved. The oldest one, by Bernardo de Lugo ([1619] 1978), is innovative in its use of symbols, but less accurate than the remaining two grammars, which are rather similar, if not overlapping, and which are accompanied by wordlists (Lucena Salmoral 1967-1970; Gonzalez de Perez 1987; Quesada Pacheco 1991). These (anonymous) grammars have been attributed to Joseph Dadey, an Italian Jesuit, known in his time as the leading specialist on the Muisca language, although there is no firm proof of his authorship. The existence of three competing grammars of this language offers a challenging field of research for descriptive and historical linguists.

The Muisca language was reported extinct in the 18th century, together with most of its close relatives and neighbors. It was the southernmost representative of the Chibchan language family, which extends into Central America (see Constenla Umana, this volume). As for the languages of Tierra Firme (today Venezuela), the Spanish missionary contribution focused on a cluster of Cariban languages comprising Cumanagoto and Chayma (Tauste 1680; Tapia 1723).

During the remainder of the colonial period, grammatical work on the major languages of South America became less important and developed a tendency towards repetitiousness. As an exception, the Chilean grammar tradition focusing on the Araucanian or Mapuche (Mapudungun) language generated two important additional works, both by Jesuits, Febres ([1764] 1975) and Havestadt (1777). While still drawing heavily upon their predecessor Valdivia, these grammars exhibit some original features. Furthermore, there was a shift of attention towards smaller surviving languages of local importance, resulting in significant and interesting 
grammars of languages such as Mochica of the northern Peruvian coast (Carrera Daza [1644] 1939), Cholon of the Huallaga valley in northern Peru (de la Mata [1748] 2007; see Alexander-Bakkerus 2005), and Lule, the language of an ethnic group of the Gran Chaco in northern Argentina that had been brought to the area of Tucuman in the 18th century (Machoni de Cerdena [1732] 1877). Many grammars produced during the colonial period were initially preserved in manuscript form without being officially published. They were published much later or not at all. Quite a few grammars that we know to have existed were lost (as in the above-mentioned case of Barzana's works). It may be that at one time grammatical sketches in

\section{camp_001.pod 6}

\section{7-10-06 13:07:39 -mu- mu}

\section{Willem F. H. Adelaar}

manuscript form were available for the languages of most of the peoples of the Spanish domain accessible to the missions, but that only few of them were preserved (or await rediscovery in some archive in South America, Italy or Spain).

A case of a published grammar that seems to have been lost is that of the Gorgotoqui language of the region of Santa Cruz de la Sierra in Bolivia by Gaspar Ruiz (Gonzales de Barcia 1737-1738). A contribution of a special kind are the wordlists of otherwise undocumented languages of northern Peru, collected by bishop Martinez Companon between 1780 and 1790 (Martinez Companon [1782-1790] 1985). During the 18th century, missionary presence in the Amazonian lowlands of Bolivia and northern Peru, as well as in the lowlands of Colombia and Venezuela, generated additional descriptive work on languages of importance for the evangelization project (Achagua, Betoi, Chiquitano, Jebero, Maipure, Moxo, Yuracare, Zamuco, etc.). Several of these grammars have remained in manuscript form, and some of them are in danger of becoming lost even today. Others were published in a modernized version at the end of the 19th century (Adam and Henry 1880; Adam 1893). A contribution to be mentioned in particular is that of Filippo Salvatore Gilij (1721-1789), an Italian Jesuit, who worked among the Tamanaco (Cariban) and Maipure (Arawakan) of the Orinoco basin. Apart from his descriptive work, Gilij (1782) can be credited for having first recognized the existence of a Maipuran or Arawakan language family, a remarkable achievement for his time (cf. Zamponi 2003b).

In comparison with the Spaniards, the Portuguese colonial authorities did little 
to stimulate the documentation of indigenous peoples and languages. All interest was focused on Tupinamba, the lingua franca or lingua geral used by Indians and non-Indians alike. Of the multitude of other languages spoken in Brazil only three were documented during the colonial period, Guarulho or Maromomim, a Purian language of coastal Sao Paulo, of which a grammar once existed but was lost (Rodrigues 1999: 166), as well as Kipea (Mamiani [1699] 1877) and Dzubukua (de Nantes [1709] 1896), two languages of the Karirian family, a branch of Macro-Je, located in northeastern Brazil (Rodrigues 1999: 170).

A most serious blow to language documentation in South America (and to native South American survival in general) came with the expulsion of the Jesuit Order from the Portuguese and Spanish domains (1759, 1767, respectively). The Marques of Pombal, responsible for the eviction of the Jesuits from Brazil, successfully organized their demise in the rest of South America and campaigned against their influence even after their forced return to Europe. (Pombal's actions may partly explain the scarcity of surviving colonial documents relating to the indigenous languages of Brazil.) Facing persecution, the Jesuit missionaries were forced to abandon their missions almost overnight. Many of them fled to Italy, taking along memories and field notes whenever possible. In the following decades, Lorenzo Hervas y Panduro (1735-1809), a Jesuit from Cuenca in Spain, collected and organized all the information he could get from his brethren in exile in a major

\section{camp_001.pod 7}

\section{7-10-06 13:07:39 -mu- mu}

Historical overview 7

overview of Jesuit knowledge in the field of South American languages (Hervas y Panduro 1784-1787, 1800-1805).

Missionaries operating in Spanish South America, the Jesuits above all, maintained and elaborated a tradition of grammar description and lexicology that had its roots in late medieval Spain. As a rule, colonial grammarians were encouraged to follow the indications and adopt the categories provided by Antonio de Nebrija in his Introductiones Latinae ([1481] 1991) and in his Gramatica Castellana ([1492] 1980). Admittedly, a rather weak point of the work of these grammarians was their poor ability to deal with the identification of speech sounds. They lacked a descriptive apparatus for this purpose and found it difficult to distinguish between sounds and symbols (letters). On the other hand, Spanish missionaries did not hesitate 
to deviate from their grammatical models by presenting newly discovered morphosyntactic categories and semantic distinctions, introducing terminology that eventually found its way into modern linguistic description. Their explanation of the distinction between inclusive and exclusive first person plural, which implies the inclusion, or respectively the exclusion of an addressee in language groups such as Quechuan and Aymaran (see, for instance, Cobo ([1653] 1890-1895), cited in Mannheim [1982]), is well known. Another example of a linguistic concept introduced by Spanish colonial grammarians working on languages such as Quechuan, Araucanian and Aymara is the notion of transiciones 'transitions', which refers to combined verbal endings specifying the grammatical person of both an agent and a direct or indirect object. A numbering system was assigned to the different combinations of grammatical person (1st acting on 2nd, 2nd acting on 1st, etc.), reflecting the way case systems are dealt with in the grammatical tradition of some European languages. The term "transition" was subsequently adopted by early representatives of the North American language-descriptive tradition, such as Peter Duponceau and Horatio Hale (Mackert 1999). It is still occasionally used in traditionbased grammars of indigenous American Indian languages produced in South American countries (e.g. in Argentina).

Jesuit missionaries were among the first to discover genetically related language groups in South America, such as the Tupi-Guaranian and Arawakan (Maipuran) language families, and to discuss controversial related issues, such as the possibility of a genetic link between Quechuan and Aymaran (Cobo [1653] 1890-1895, cited in Cerron-Palomino 2000: 298). For a long time, the work of Spanish colonial grammarians was cast aside by modern linguists as unreliable because of their alleged adherence to "the Latin model". In addition to this being only partly true, the fact that these grammarians are not even worth a mention in contemporary historical accounts of language studies and linguistics is surprising, if not grossly unfair. The last two decades have witnessed a reappraisal and a renewed interest in the writings of Spanish colonial grammarians. They are now studied in their own right and no longer as incidental sources of consultation only (Suarez Roca 1992; Zimmerman 1997; Zwartjes 2000).

\title{
camp_001.pod 8
}

\section{7-10-06 13:07:39 -mu- mu}

\author{
8 Willem F. H. Adelaar
}


The most important work on a language spoken beyond the borders of the Spanish and Portuguese domains is without any doubt that of Raymond Breton on the language of the Island Caribs of the Lesser Antilles, as spoken on the island of Dominica in the 17th century (Breton [1665] 1999, [1666] 1900; Adam and Leclerc 1878). In the area of the Guyanas (protestant) Moravian missionaries, also known as Herrnhuters, contributed to the knowledge of the local languages. A grammar and a dictionary of the Arawak language by Theophilus Salomon Schumann were written between 1752 and 1763, and published in 1882 (van Baarle 1999). The final years of the 18th century brought a resurgence of interest in the indigenous languages of South America, which was stimulated by improved relationships between the enlightened Bourbon administration in Madrid and other European rulers, including rulers of non-Catholic nations. An event of particular importance consisted in the efforts of the Russian empress, Catherine the Great, to collect data for a world-spanning project to document all languages of the globe. In order to meet Catherine's wish, the Spanish King ordered his representatives in the New World to collect word-lists and other materials on the indigenous languages spoken in their jurisdictions (Dedenbach-Salazar Saenz 2006). Although much of the collected materials never reached Russia, the Empress's interest incited local researchers to search for available samples of language documentation after a long period of neglect. As a result, all sorts of documents of linguistic relevance found their way to Spain. Some of them would eventually contribute to overview works dealing with the languages of the world, such as Pallas ([1786-1789] 1977-1978), Yankievich de Mirievo (1790-1791) and Adelung and Vater (1806-1817).

\section{The nineteenth century}

The beginning of the 19th century roughly coincides with the opening up of the Spanish and Portuguese domains in South America to foreign travelers and researchers. At that time, European intelligentsia showed a great interest and curiosity towards everything the New World had to offer, including the native languages.

European rulers financed and stimulated ambitious scientific expeditions in order to remedy the general lack of knowledge on a long neglected continent. Scientisttravelers such as Alexander von Humboldt (1769-1859), Karl Friedrich von Martius (1794-1868) and Alcide d'Orbigny (1802-1857) contributed immensely to the initial assessment of ethnic and linguistic diversity in South America.

For the scientific reflection on language and linguistic diversity, a special mention should go to Alexander von Humboldt's elder brother, the Prussian linguist 
and philosopher Wilhelm von Humboldt (1767-1835). Humboldt's aim was to develop a modern interpretation of the grammatical descriptions dedicated to New World languages that had been inherited from the colonial grammar tradition. To this end, he based himself, inter alia, on grammatical summaries provided (and

\section{camp_001.pod 9}

\section{7-10-06 13:07:39 -mu- mu}

Historical overview 9

written) by Hervas y Panduro (Ringmacher and Tintemann, 2011). A recurrent element in Humboldtian thinking is the conviction that formally similar elements must be identical historically, if not synchronically, in spite of observed differences in meaning and function. For instance, von Humboldt attributed particular significance to the fact that in Araucanian the verbal suffix indicating a 1st person singular subject and the nominalizing suffix that marks the infinitive (both - $(i) n$, as in lef in 'I ran' and 'to run') are formally identical. He also assigned a hierarchical ranking to languages depending on whether or not tense and aspect markers are located nearer to the verbal base than personal reference endings. Languages of the former type, such as Araucanian, Aymaran and Quechuan, are similar to IndoEuropean in this respect and, consequently, were accorded a higher position on a developmental scale than languages of the latter type, represented by the TupiGuarani and other Amazonian languages. Although such assumptions have not produced a lasting effect, Humboldt's approach to the New World's languages represented a new way of thinking about language. It also constituted a radical departure from the traditional prescriptive discourse of the colonial grammarians, thus anticipating the birth of modern linguistics.

Nevertheless, Humboldt's considerations regarding the structure and essence of the Amerindian languages were exceptional for the first half of the 19th century. The curiosity of the scientific travelers who were rediscovering South America incited them to document large numbers of hitherto unknown languages with limited means and limited time. The collection of vocabulary lists for numerous languages that could offer a basis for a first tentative genetic classification became a priority and a common practice during the 19th century. It would continue well into the 20th century.

The marriage of a Habsburg princess with the heir to the Brazilian imperial throne made it possible for the Austrian emperor to send a scientific expedition to 
Brazil. This expedition, headed by Karl Friedrich von Martius and Johann Baptist von Spix, took place between 1817 and 1820. One of the members of the expedition, Johann Natterer, obtained permission to stay on in Brazil after the return of the expedition. He succeeded in collecting vocabulary lists with ethnographic data from 72 ethnic groups of the Amazonian region and adjacent areas (Kann 1989). For this purpose, Natterer used a standard wordlist developed by von Eschwege (1818), which had already been used for the collection of vocabulary from languages of eastern Brazil. Although the bulk of Natterer's material remains unpublished, 1 some of his lists were later included in another extensive collection of Brazilian materials published by von Martius (1867). Further data on indigenous languages from the interior of Brazil were collected in 1822-1829 during a Russian expedition headed by Georg Heinrich von Langsdorff. One of its members, the Frenchman Edouard Menetries collected extensive vocabularies of Purian and Botocudoan (Krenakan) languages spoken in eastern Brazil (Komissarov 1994). Fifty years later, during the Triple Alliance War with Paraguay, the Brazilian Viscount of

\section{camp_001.pod 10}

\section{7-10-06 13:07:39 -mu- mu}

10 Willem F. H. Adelaar

Taunay collected vocabulary lists from an Indian woman of the Guana or Chane (Arawakan) nation, with whom he entertained a romantic relationship (Taunay 2000).

Ethnographic data and vocabulary lists of the languages spoken in the southern part of the former Spanish domain (especially southern Peru, Bolivia, Argentina, Chile, Paraguay and Uruguay) and in southern Brazil were collected by the French traveler and scientist Alcide d'Orbigny. He paid special attention to the languages spoken in the former missions of Moxos and Chiquitos in the eastern Bolivian lowlands, which had been abandoned by the Jesuits at the time of their removal (d'Orbigny 1839). In the Chiquitos area he recorded a unique situation of multilingualism, in which a number of smaller languages belonging to different families (Arawakan, Bororoan, Chapacuran, Tupi-Guaranian and Zamucoan) were in the process of being absorbed by the dominant Chiquitano language. Most of these languages have since then disappeared, although a few remnants of Paunaca (Arawakan) remain (Danielsen forthcoming).

The tradition of Quechuan studies was continued during the 19th century by the 
Swiss scholar Johann Jakob von Tschudi (1818-1889), by Sir Clements Markham from Great Britain (1830-1916) and by the German physician Ernst W. Middendorf (1830-1908). All three produced dictionaries, grammars and translations of the early 18th century Ollantay drama. Middendorf deserves a special mention for his thorough and elaborate studies of the Andean languages Quechua, Aymara, Mochica and Muisca (1890-1892). Middendorf's grammar of Cuzco Quechua was to become the most modern work on this language group until the second half of the 20th century. His grammar of Mochica contains much unique data of a highly complex language on its way to extinction, which had suffered radical transformations since it was described by Carrera in 1644. Following the habit of his time, Middendorf apparently combined the data brought together by Carrera with his own findings in a modernized presentation, occasionally referring to German dialects in order to explain phonetic detail. He also collected some short texts, which are the only non-religious textual data available for the Mochica language and which clearly show the phonological transformation that the language had undergone during the previous two and half centuries.

Between 1871 and 1903 several missionary grammars were made known through the series Coleccion Linguistica Americana, subsequently Bibliotheque Linguistique Americaine initiated by the Colombian Ezequiel Uricoechea. Uricoechea's work focused on languages of Colombia, such as Muisca and Paez, and was partly based on unpublished colonial manuscripts. In the same series, the Frenchman Lucien Adam published original or updated versions of colonial work, including manuscript grammars of Arawakan languages (Arawak, Guajiro, Moxo), Guaicuruan languages, Chiquitano, and Yuracare.

In Chile, Rodolfo Lenz published a series of studies on the Araucanian language, its dialectology, its oral literature and its traditions (Lenz 1895-1897), thus

\section{camp_001.pod 11}

\section{7-10-06 13:07:39 -mu- mu}

Historical overview 11

further contributing to the status of Araucanian or Mapuche as one of the most soundly documented indigenous languages in the Americas. Lenz also ventured some controversial ideas about the role of an alleged Mapuche substratum in the Chilean variety of Spanish (Lenz 1905-1910). These ideas met with ferocious opposition among purist Hispanicist circles and continue to arouse heated debates to 
this day.

One of the greatest achievements of the 19th century in the field of South

American languages was Thomas Bridges' dictionary of the Yahgan language,

native to an archipelago situated south of the main island of Tierra del Fuego. Thomas

Bridges (1842-1898), a protestant missionary and self-made linguist, spent

much of his life around Tierra del Fuego. The manuscript of his monumental dictionary of this unique linguistic isolate, now on the verge of extinction, was published after many vicissitudes (Bridges 1933). The orthography and the presentation of Bridges' work merit a detained study themselves.

The end of the 19th century witnessed more expeditions into the Amazon, notably by Karl von den Steinen in the Xingu area, who wrote a grammatical study of Bakairi (Cariban) (1892). Paul Ehrenreich (1894) published data on several Brazilian languages, including Karaja (Macro-Jean) and Kaiapo (Jean). In Colombia, Guajiro (Arawakan), Kogui (Chibchan) and other languages spoken in the northeastern part of the country were studied by the missionary Rafael Celedon $(1878,1886)$.

In spite of remarkable exceptions such as Humboldt, Middendorf and Bridges, the 19th century was a period of stagnation as far as the study of the South American indigenous languages was concerned. It did not follow the pace of development of Indo-European language studies and those of other important language groups of the Old World. During the 19th century the colonial achievements in the description of grammars of American Indian grammar were hardly remembered, much less continued. However, towards the end of the 19th century, there was a first attempt at attaining a genetically-based classification of the South American languages in Daniel Brinton's work on the languages of the Americas (Brinton 1891). In the same period we may place Max Uhle's identification of the (typologically very heterogeneous) Chibchan language family (Uhle 1890) and his unpublished work on the Uru language (Uhle 1895). In Argentina, Bartolome Mitre, author, military man and president of the nation in 1862-1868, brought together a large amount of information on the languages of southern South America and other parts of the New World. His work was published posthumously (Mitre 1909-1910). Another Argentinean scholar, Samuel Lafone Quevedo published extensively on the languages of his country, those of the Gran Chaco in particular (Lafone Quevedo 1893, 1895, 1896).

\section{camp_001.pod 12}


07-10-06 13:07:39 -mu- mu

12 Willem F. H. Adelaar

\section{The first half of the 20th century (1900-1960)}

In the 20th century, the study of the South American Indian languages had a slow start. Systematic in-depth research on the surviving languages continued to be neglected during the first decades, as it had been in the 19th century. A remarkable exception was the linguistic activity of Bavarian Capuchin missionaries in southern Chile. The grammar, dictionaries and anthologies of the Mapuche language produced by Felix de Augusta ([1903] 1990, [1916] 1966, [1916] 1991) and Ernesto de Moesbach (1963) reflect a relatively modern view of language. The Capuchins' work benefitted from the oral traditions recorded from survivors of the pacification war against the Araucanians, who had maintained their independence from Chile until 1882. Remarkable for the display of rhetoric and the use of extraordinarily complex sentences are the war memories of Pascual Cona, one of the Mapuche chiefs who had survived the pacification (Moesbach 1930; Cona 1984). Detailed information on the languages of Tierra del Fuego can be found in the work of the Austrian missionary Martin Gusinde (1926, 1931-1937).

In the meantime, advances were also made in the area of the Amazonian languages. The study of Kaxinawa (Panoan), written by the Brazilian Capistrano de Abreu ([1914] 1941), was one of the first language descriptions of a South American language of the 20th century. Marshall Candido Rondon (1865-1958), who in 1910 founded the Brazilian agency for the protection of the Indians (SPI), published wordlists of indigenous languages from different areas of Brazil (Rondon and Barbosa de Faria 1948). Also in the service of the SPI, the ethnologist Curt Nimuendaju (1893-1945, born Curt Unckel), contacted many tribes, collecting numerous wordlists of little known languages and formulating intuitions about their genetic affiliation. One of Nimuendaju's most famous publications is that of the Apapokuva myths, recorded from a Chiripa Guarani tribe that he was commissioned to relocate in the state of Sao Paulo (Nimuendaju 1914). Nimuendaju published one of the first structured language maps of Brazil (Nimuendaju [1944] 1981) and suggested several genetic links among native languages of Brazil, which would be confirmed later. Also, Guerios wrote several studies on little known Macro-Jean languages of eastern Brazil (e.g. Guerios 1945). Also in relation to the Amazonian area, the Dutchman Claudius de Goeje (1935) studied the historical relations of the languages of the Guyanas (Arawakan, 
Cariban and Warao), as well as Karirian in northeastern Brazil. His suggestion that Cariban and Karirian (a branch of Macro-Jean) may be distantly related seems to receive additional support in recent research by Rodrigues (2000), who found coincidences connecting Cariban, Tupian and Macro-Jean. The German ethnographer Theodor Koch-Grunberg (1872-1924) collected language data on his 1903-1905 and 1911-1913 expeditions to the Rio Negro and the area north of the Amazon (Koch-Grunberg 1909-1910, 1913, 1917, 1928). The British colonel P. H. Fawcett (1867-c. 1925) was one of the first to record language data from

\section{camp_001.pod 13}

\section{7-10-06 13:07:39 -mu- mu}

Historical overview 13

Rondonia, later followed by the German anthropologist Emil Heinrich Snethlage (1897-1939) and the Swiss anthropologist Franz Caspar (1916-1977). Much of these data only exist in manuscript form.2

In the first decades of the 20th century all-round German Americanists such as Eduard Seler (1849-1922), Robert Lehmann-Nitsche (1872-1938) and Walter Lehmann (1878-1939) contributed substantially to the knowledge of small languages in the Andean region and the southern extreme of South America (e.g. Chonan languages, Uru-Chipayan, Mochica and Esmeraldeno). Unique unpublished data on languages now extinct collected by Lehmann (e.g. Uru of Ch'imu) can be found in the library of the Ibero-American Institute in Berlin. To this list we can add Gunter Tessmann's work on the peoples and languages of the Peruvian Amazon (Tessmann 1930). The Swedish ethnographer Erland Nordenskiold (1877-1932) collected much valuable data (often unpublished) on a wide array of languages, including those of the Bolivian lowlands, genetically one of the most complex regions of South America (cf. Nordenskiold 1924). Several contributions to our knowledge of small, presumably extinct languages of the Andean region can be credited to Rudolph R. Schuller (1873-1932).

In France, the study of South American languages in the first half of the century was dominated by Paul Rivet (1876-1958), the founder and long-standing director of the Musee de l'Homme in Paris. Rivet's contributions to the documentation of minor, often extinct languages and his talent in disclosing rare and little known sources, especially those relating to the northwestern part of South America (Landaburu 1996-9), were extremely important. The rich holdings of his linguistic 
archive in Paris have inspired many researchers. Rivet obtained most of his materials from historical sources or from people working in the field, such as the missionary Constant Tastevin, stationed in Tefe on the upper Amazon River in Brazil. Rivet's often extravagant views on the genetic classification of the South American languages fared less well. Among his more extreme proposals, which have not survived posterior critical scrutiny, are his attribution of the Yurumangui isolate in Colombia to the North American Hokan family (Rivet 1942; cf. Poser 1992) and the supposition that some South American language families were genetically linked to languages of the Australian aborigines (Rivet 1925). A most important contribution is the monumental bibliography of the Aymara and Quechua languages compiled by Rivet and de Crequi-Montfort (1951-1956). Together with C` estmir Loukotka, a Czech linguist, Rivet also contributed to Meillet and Cohen's Les Langues $d u$ Monde (1952) with a classification of the South American languages. Later on, Loukotka elaborated his own classification, comprising 117 language families or isolates, posthumously published (Loukotka 1968). Loukotka's classification is conservative and reliable in that few controversial groupings are included, it being organized according to geographical criteria. His catalogue-like work, which contains a rich bibliography as well as short samples of basic vocabulary for as many languages as turned out to be sufficiently documented, became immensely

\section{camp_001.pod 14}

\section{7-10-06 13:07:39 -mu- mu}

14 Willem F. H. Adelaar

popular as a browsing and discovery tool for intended comparative linguists. Nevertheless, its suitability for the detection of genetic links among languages is limited as it hardly goes beyond the possibility to recognize non-controversial affinities. In this way, Loukotka's work, which remained without rival for a long time, contributed to the prevailing opinion of extreme genetic diversity attributed to the languages of South America. A similar bibliographical catalogue but without wordlists is Tovar (1961) and, especially, its revised version (Tovar and Larrucea de Tovar 1984). In Argentina, toponymy, in particular of the northwestern part of the country with its indigenous past, became an issue of local interest (Lafone Quevedo 1927), and the possibility of a linguistic contact between South America and Polynesia was addressed by Imbelloni and Palavecino (Imbelloni 1926). The Ecuadorian 
scholar Jacinto Jijon y Caamano (1890-1950) studied scores of languages of Central America and the northwestern part of South America, as well as their mutual relations, in order to establish the connections that were relevant for the languages of his motherland (Jijon y Caamano 1940-1945). He collected much toponymical data relating to extinct languages of the Ecuadorian highlands and coast in an effort to identify and reconstruct the original areas of the pre-Quechuan languages. Like Rivet, Jijon y Caamano proposed many genetic connections that were never substantiated. However, his contributions to the toponymy of Ecuador and to the morphology of little known languages, such as the coastal Esmeraldeno, are valuable. More work on pre-Quechuan toponymy of Ecuador comes from Luis Paz y Mino (1936-1937, 1940-1942, 1961a, 1961b). An interesting overview of the languages of South America, with much unexpected detail, is Ibarra Grasso (1958). Jean Vellard (1950-1951) was one of the last researchers to collect reliable data on the Uru language of the Desaguadero basin in the Peruvian-Bolivian border area. In Venezuela the Jirajaran and Timote-Cuica languages of the Andean region and its foothills were about to become extinct at the beginning of the 20th century. Local and foreign researchers managed to collect some data before the eventual disappearance of these languages (Oramas 1916; Jahn 1927). Rivet (1927) reorganized and discussed most of what was known about the Timote-Cuica family. More classificatory overviews of the South American languages were provided by Mason (1950) and McQuown (1955). They were soon followed by the more ambitious efforts of Greenberg (1959, 1960a, 1960b) and Swadesh $(1959,1962)$. Whereas the two former classifications were mainly inventories with occasional proposals of genetic grouping, the latter two constitute an attempt at accommodating all the South American languages in a complex framework of groups and subgroups. However, Greenberg's Indo-European-style tree concept contrasts with Swadesh's network approach. None of these classifications was accompanied by the empirical evidence an independent verification would require. As far as Greenberg's proposal is concerned, this shortcoming has partly been addressed in Greenberg (1987), where the data underlying his (revised) classification are presented.

\section{camp_001.pod 15}

$$
\text { 07-10-06 13:07:39 -mu- mu }
$$

Historical overview 15

\section{The Summer Institute of Linguistics}

The Summer Institute of Linguistics was founded in 1934 by William Cameron 
Townsend as a sister organization to Wycliffe Bible Translators. Its primary aim was to document the languages of the world, regardless of their official status and number of speakers, so as to facilitate community work and the production of Bible texts in native languages. For this purpose, linguists associated with the Summer Institute of Linguistics, in particular Kenneth Pike $(1943,1947)$ and Eugene Nida (1943), developed phonetic, phonological and morphological methods on the basis of American Indian field data that were used in language-descriptive work worldwide. The Summer Institute of Linguistics, presently known as SIL International and, in Spanish speaking countries, as Instituto Linguistico de Verano or ILV, has founded a tradition of linguistic research that reaches the most remote indigenous language communities in Latin America. Although the activities of SIL started in Guatemala and then Mexico, its work became increasingly important in South America as well after mid century. SIL deployed its activities in all South American countries with a substantial indigenous population, except for Argentina, Paraguay and Venezuela, and managed to build up a large archive of unique language data which is accessible to linguists of all kind. The Brazilian, Colombian, Ecuadorian and Peruvian branches of SIL became particularly important, the latter three with jungle bases at Lomalinda (Meta), Limoncocha and Yarinacocha, respectively. Initially, descriptive work by SIL members was cast in a rather impenetrable formalized morphosyntactic framework, known as Tagmemics (see, for instance, Elson 1963; Matteson 1967), which was gradually replaced by more functionoriented descriptive models. Overall grammatical studies by SIL members are Matteson on Piro (1965), Wiesemann on Kaingang (1972), Allin on Resigaro (1976), Derbyshire on Hixkaryana (1979), Weber on Huallaga Quechua (1989) and several studies found in Derbyshire and Pullum (1986-1998).

A great advantage of the activity of SIL is its extensiveness with regard to the number of languages treated. In Peru practically all the jungle languages have been studied, a fact that is reflected in the rich materials published in the Serie Linguistica Peruana, which includes dictionaries, grammars, primers, etc. For quite a few languages (e.g. Amuesha, Chamicuro, Muniche, Resigaro, etc.), SIL materials provide the main available sources. Until the 1990s this probably held true for most of the indigenous languages in South America. SIL language descriptions differ widely in their size and degree of sophistication. Along with highly complex grammars and linguistic essays, other materials are more rudimentary. An important achievement of the SIL is the Ethnologue, a periodically updated publication, available both in 
book form and online, that contains basic information on the languages of the world including a division on South America. The editors of the Ethnologue have played a central role in the development of the ISO coding system for the identification of individual languages, which is now in use among non-SIL linguists as well.

\section{camp_001.pod 16}

\section{7-10-06 13:07:39 -mu- mu}

16 Willem F. H. Adelaar

In some countries, such as Peru, SIL as an institution has contributed to the national educational system directed towards the Amazonian language communities, with efforts to develop bilingual education programs. SIL members also have played a prominent role in discussions about orthographic choices to be made in processes of spelling standardization (see, for instance, Weber 1994).

\section{Dialect surveys in the Andes and the first grammatical descriptions}

Before the 1960s, modern linguistic descriptions of South American indigenous languages were practically non-existent. The availability of descriptive work such as that of Capistrano de Abreu (see above) was highly exceptional. For some of the major Andean languages one had to have recourse to pre-modern, traditional grammars, some of them from the beginning of the colonial period, or work directly based on such colonial grammars. The precarious situation of the numerous surviving lowland languages with their dwindling speaker numbers, most of them almost completely unknown, made it seem an impossible task to record them all, and it appeared that the unique South American language diversity was bound to disappear before a full-scale documentation had even begun.

Nevertheless, interest in and curiosity for the contemporary spoken varieties of the South American languages were growing, also among non-missionary linguists. One of the first American Indian language groups to receive systematic and focused attention on a modern linguistic basis was Quechuan, in particular, its Peruvian varieties. Until the 1960 s, a historical myth assigning to the Cuzco variety of Quechuan the status of the imperial "Inca" language, rooted in the former capital of the Inca empire (Cuzco), was seldom questioned. Under this assumption the complex dialect situation of Quechuan was interpreted as a sign of linguistic decay, a viewpoint firmly defended by the Quechua Language Academy in Cuzco (see below). In the early 1960s, dialect surveys conducted by Gary Parker (1963) and Alfredo Torero (1964) brought to light a fundamental internal differentiation within the Quechuan language complex, already foreshadowed in an article by Ferrario 
(1956). Such differences could not be explained within the timeframe of the four centuries following the conquest and indicated a deeply rooted diversification of ancient date. These findings underscored the urgency of studying the numerous local varieties of Quechuan ("dialects") as languages in their own right, an activity which was to continue until well into the 1980s. Some examples of descriptions of Quechuan languages are Adelaar (1977, 1987), Cerron-Palomino (1976a), Cusihuaman (1976a), Cole (1982), Lastra (1968), Parker (1969, 1976), Taylor $(1975,1982)$ and Weber (1989). Additional work with a strongly generative focus is found in Muysken (1977) and Lefebvre and Muysken (1988). The Quechuan variety of Santiago del Estero in Argentina was addressed by a separate research tradition in early work by Bravo (1956) and more recent publications by Alderetes

\section{camp_001.pod 17}

\section{7-10-06 13:07:39 -mu- mu}

Historical overview 17

(2001) and, posthumously, in the work of Nardi (2002). Also from the 1960s on, Aymara and its sister language Jaqaru became the object of detailed descriptions (Hardman 1966, 1983, 2000; Hardman et al. 1974, 1988; Porterie-Gutierrez 1988). The relatively early date of most descriptive work on the major Andean languages necessarily implies that it was not yet heavily influenced by the advances in functional and typological linguistics that characterize most present-day descriptions of South American languages.

The focus on language description relating to the central Andean region logically led to the publication of a number of synthetic works that had the objective of organizing and evaluating dispersed information on different linguistic varieties and interpreting newly obtained data in an archaeological and a historical context. Torero (1974) studies the Quechuan language group and its many varieties in a social and historical context. Torero (2002) is a synthesis of earlier publications supplemented with the results of new research, especially on the minor languages of the Andean area. Cerron-Palomino (1987) and Cerron-Palomino (2000) are dedicated to the linguistics of the Quechuan and Aymaran language families, respectively. Dialect variation within the Aymara language was studied by Briggs $(1976,1993)$. Adelaar with Muysken (2004) is an overview of the Andean languages covering the western part of South America from north to south. The rather underrepresented field of area linguistics was addressed in Buttner (1983), and as 
far as the northern part of the Andean region is concerned in Constenla Umana (1991).

\section{Grammatical description and historical-comparative research towards the end of the 20th century}

Grammatical descriptions of languages not belonging to the central Andean region that date from the period before 1990 (beside publications by SIL linguists) are Mosonyi (1966) on Yaruro, Gregores and Suarez (1967) on Paraguayan Guarani, Lapenda (1968) on Fulnio, Hoff (1968) on Carib, Lizot $(1970,1975)$ and Migliazza (1972) on Yanomamo, Vinas Urquiza (1974) and Tovar (1980) on Mataco (Wichi), Klein (1978) on Toba, Olza and Jusayu (1978) on Guajiro, Landaburu (1979) on Andoke, Seelwische $(1975,1980,1990)$ on Nivacle, Grenand $(1980,1989)$ on Wayapi, Gomez-Imbert on Tatuyo (1982), Carson (1982) on Makuxi, Helberg (1984) on Amarakaeri, Dietrich (1986) on Chiriguano, Clairis (1987) on Kawesqar, Patte (1989) on Paraujano, and van Baarle et al. (1989) on Lokono (Surinam Arawak). Languages of the Paraguayan Gran Chaco are addressed in a series of publications by Sušnik (1958, 1977, 1986-1987).

In Colombia a first overview of the complex language situation was provided by Ortiz (1965). In the 1980s a center for the education and training of local linguists (CCELA) was established at the Universidad de Los Andes in Bogota with

\section{camp_001.pod 18}

07-10-06 13:07:39 -mu- mu

18 Willem F. H. Adelaar

the support and coaching of the French research organization CNRS. This center specialized in the description and documentation of the indigenous languages of Colombia, and has generated much research and a great number of publications since 1987. Gonzalez de Perez and Rodriguez de Montes (2000) provide a monumental overview of all the previous research on the languages of Colombia, including work by CCELA, SIL and the Caro y Cuervo Institute in Bogota.

Linguists from Argentina have long been actively involved in the study and documentation of the indigenous languages of that country and its neighbors. The main center of research is the Faculty of Letters of the University of Buenos Aires, which has organized several international meetings in this field. Before 1990, Argentinian linguists produced grammars of Selknam (Najlis 1973), Chorote (Gerzenstein 1978-1979) and Gununa Yajich (Casimiquela 1983).

In the meantime, a number of state-of-the-art books concerning large areas 
cleared the way for a systematic treatment of the languages of South America in general or of specific areas, in particular, the Amazonian region. Among the first were Key (1979), Pottier (1983), Klein and Stark (1985) and Migliazza and Campbell (1988). The essays brought together in Payne (1990) were among the first to highlight the typological peculiarities of the Amazonian languages, which would receive more and more attention during the following years. A small, but influential study focusing on the languages of Brazil is Rodrigues (1986). A more recent overview article of the South American language situation is Kaufman (1994). Campbell (1997) is remarkable for its focus on historical linguistics and for the fact that it offers a pan-American perspective. Dixon and Aikhenvald (1999) offer an overview of the languages of the Amazonian region. An overview of the western, Pre-Andine sector of the Amazonian languages can also be found in Adelaar with Muysken (2004). A useful compilation of articles with an excellent set of maps of the situation in each of the countries with an Amazonian sector can be found in Queixalos and Renault-Lescure (2000).

The four last decades of the twentieth century have not brought a decisive breakthrough in the overall genetic classification of the South American languages. Kaufman's (1990) comprehensive classification still contains as many different families as Loukotka's of 1968, although a grouping of families is suggested for some areas (e.g. Macro-Jean, see below). It should be observed, however, that the classifications of Loukotka and Kaufman do not coincide, and that some language groups that were unduly combined in the former (in paticular, within the proposed Arawakan and Chibchan groupings) are recognized as separate units in the latter. Suarez's (1974) classification proposes a moderate reduction of the number of genetic units comprised in Loukotka, but it does not offer any systematic presentation of arguments. The most radical proposal is Greenberg's (1987), which groups all the South American and Mesoamerican languages into a single phylum, Amerind, together with a majority of the North American languages. In contrast with Greenberg's earlier classifications, the book Language in the Americamp_

\section{1.pod 19}

\section{7-10-06 13:07:39 -mu- mu}

Historical overview 19

cas (Greenberg 1987) presents a selection of the database underlying his proposals.

Not only are all South American languages considered related, they are also subject 
to sub-grouping. Greenberg's subgroups have been met with skepticism for a number of reasons, including the underanalyzed nature of the presented data, the perpetuation of old misunderstandings (especially those generated by Rivet), and the fact that recent findings may suggest entirely different groupings. At least in some cases, however, Greenberg's contribution seems to be valuable, namely, when he presents evidence for the inclusion of Chiquitano and Jabutian in MacroJean (cf. Adelaar 2008; Ribeiro and van der Voort 2010). One of the proposals that are in conflict with Greenberg's classification is Rodrigues's view that Cariban and Tupian may be related (Rodrigues 1985). It lies at the basis of a very promising development, which also involves the Macro-Jean hypothesis (Rodrigues 2000). The awareness that a Macro-Jean grouping comprising Jean itself and several small families in Brazil may be a valid idea slowly gained ground during the last decades of the 20th century (Davis 1968; Rodrigues 1986; Greenberg 1987; Kaufman 1990). Another important development is Constenla's (1981) deconstruction of the unsubstantiated and confusing macro-Chibchan hypothesis advocated by Rivet, Jijon y Caamano and Greenberg. More limited proposals for genetic linkings can be found in Aschmann (1993) for Boran and Huitotoan, Curnow and Liddicoat (1998) for the inclusion of Guambiano in Barbacoan, and Adelaar (2000) for Harakmbut and Katukinan.

\section{Official recognition of indigenous languages and the rise of normative grammar}

The normative approach to the indigenous languages of South America has a long history. Notwithstanding a few dissident views, the Spanish and Portuguese authorities were not particularly keen to impose their own languages on the Indian population until the second half of the 18th century. The language policy adopted by colonial administrators and church representatives was to select so-called lenguas generales or linguas gerais ('general languages') in order to bridge the gap between a multitude of ethnic groups speaking different languages and in order to facilitate communication between these groups and the Spaniards or Portuguese. Logically, such a policy favored the use of languages that already had a significant distribution in pre-conquest times: a variety of Quechuan and Aymara in the central Andean highlands, Araucanian in Chile, Muisca in New Granada (Colombia), Guarani in the basins of the Paraguay and Parana rivers, and Tupi or Tupinamba in the Brazilian coastal region extending from the present-day state of Sao Paulo all the way up to the mouth and lower course of the Amazon river. In addition, languages of a more limited reach, such as Siona, Saliva, Chiquitano and Moxo, were 
selected in order to unify particular missionary provinces. In the case of languages

\section{camp_001.pod 20}

\section{7-10-06 13:07:39 -mu- mu}

\section{Willem F. H. Adelaar}

spoken by millions of individuals with substantial internal differences the need for normalization and unification became an issue at an early stage of the colonial enterprise (see Section 2 for the case of Quechuan).

The fate of the Guarani language in Paraguay was closely connected with the successful efforts of the Jesuits to establish autonomous safe areas (reducciones) for the indigenous population during the 17th and 18th centuries. Although the indigenous communities were left in a state of abandonment after the eviction of the Jesuits in 1768, Guarani survived as the dominant language of the Paraguayan countryside and in the adjacent provinces of Corrientes and Misiones (now part of Argentina). The awareness of having a distinct linguistic identity gained momentum during the nationalistic upswing that accompanied two wars in which the Paraguayans were pitted against their neighbors (the Triple Alianza War of 1864-1870 and the Gran Chaco War of 1932-1935). The Guarani language became a symbol of the Paraguayan national identity to both Indians and non-Indians. In the Constitution of 1962, Guarani was recognized as one of the national languages of Paraguay, while the 1992 Constitution made it an official language on an equal footing with Spanish (Melia 1992). Since spoken Paraguayan Guarani is heavily influenced by Spanish, the need for normalization and a concern for linguistic purism gained importance during the second half of the 20th century. These trends are reflected in the work of Antonio Guasch, whose grammar (E1 Idioma Guarani) and dictionary of the Guarani language have been the object of several consecutive editions (Guasch 1956, 1981). Whereas Guasch's dictionary introduces Guarani terms for neologisms such as "astronaut" and "ballpoint pen", his grammar presents a full system of decimal number terms, which partly consist of artificially invented items completed with body part terms. (Originally, Guarani had only four true numerals.) Invented terms also figure on official Paraguayan banknotes (Melia 1992: 174.) A problem, however, is that alternative sets of invented terms are in use for the purpose of denoting the higher numbers. The Decoud Larrosa system used on the banknotes and in education is different from that of Guasch (Krivoshein de Canese 1983: 52). Recent publications of CEPAG (Centro de Estudios Paraguayos "Antonio 
Guasch"), under the responsibility of Bartomeu Melia, present a more realistic level of purism than Guasch's publications did.

In Peru efforts towards a standardization of the Quechuan language group are often associated with the Academia Mayor de la Lengua Quechua, established in the ancient Inca capital Cuzco. This academy, established in 1958 as Academia Peruana de la Lengua Quechua, obtained its present denomination in 1990, and has its roots in the cultural indigenista movement that flourished in southern Peru in the first half of the 20th century (Marr 1999). Its protagonists have always been mestizo intellectuals from the Cuzco region with a strong predilection for the local form of Quechua and its Inca roots. The latter is frequently hailed as the "imperial" variety of Quechua in contradistinction with other dialects that are considered inferior or "degenerate". The Academia owes much of its clout to the fact

\section{camp_001.pod 21}

\section{7-10-06 13:07:39 -mu- mu}

Historical overview 21

that it has been officially entitled to establish the correct form of Quechua to be used in the Peruvian Constitution. Its main feats of arms are a much debated QuechuaSpanish Spanish-Quechua dictionary (Academia Mayor de la Lengua Quechua 2005) and a lasting influence on the Quechua spelling habits used in Cuzco and its environs. The Academia Mayor de la Lengua Quechua copies European language academies (especially that of Spain) in its claims to power of decision and infallibility. The total rejection of any valorization of the numerous Quechuan varieties spoken in Peru, other than Cuzco Quechua, and the dogmatic identification of the origins of Quechua with the rise of Inca power in Cuzco put the Academia Mayor de la Lengua Quechua on a collision course with Peruvian and foreign university linguists that place the origin of Quechuan in the central coastal and Andean region of Peru at a date that precedes the Inca empire by more than a millennium.

In 1975, the then military government of Peru issued a decree that made Quechua the second official language of the country. All of a sudden, the issue of language normalization became urgent. Linguists and educators had been divided on whether to introduce a unified type of Quechua as a standard language, or to preserve local varieties. The dialectological research of the 1960s and 1970s, summarized in Torero (1974), had clearly shown that the differences between regional 
varieties could be substantial, and that in some areas the introduction of one specific variety of Quechuan might be experienced as the imposition of yet another foreign language. As a result, a compromise was elaborated by subdividing Peruvian Quechuan into six different languages, each represented by a specific standard "dialect" or dialect complex. Within all but two of these six selected "languages", the dialect differences were so great that many speakers could hardly be expected to identify with them. However, the selection of the six language norms set about a fair amount of linguistic activity as the Peruvian government commissioned sets of grammars and dictionaries for each of them. This series of grammars and dictionaries, coordinated by Alberto Escobar, was written and published in a short lapse of time and became very influential (Cerron-Palomino 1976a, 1976b; Coombs, Coombs and Weber 1976; Cusihuaman 1976a, 1976b; Quesada 1976a, 1976b; Park, Weber and Cenepo 1976; Parker 1976; Parker and Chavez 1976; Soto Ruiz 1976a, 176b). At least one of the aforementioned descriptions, Cerron-Palomino's grammar and dictionary of the Junin-Huanca norm, represents a reconstructed proto-variety intended to serve as a norm for three descendant dialect varieties (Jauja, Concepcion and Huanca) and their sub-varieties. For instance, the presentation contains a phoneme symbol $q$, reconstructible as a uvular stop, which has suffered distinct developments in the descendant dialect varieties. Norm-inspired choices, often based on previous stages of development of the language varieties to be codified or using complementary resources from different dialects, have become a recurrent phenomenon in much of the subsequent literature on Andean languages. They form part of an ongoing effort to handle linguistic diversity in

\section{camp_001.pod 22}

\section{7-10-06 13:07:39 -mu- mu}

\section{Willem F. H. Adelaar}

the face of an all-dominant and fully normalized language of communication (Spanish).

Throughout the 1980s and 1990s, spelling discussions dominated the debate on language normalization in the Andean countries. Conflicting spelling habits separated speakers of Ecuadorian Quechuan from those of Bolivian and Peruvian varieties, a contradiction that was only lifted in 1998 (Howard 2007). A more acerbic issue was the discussion about the number of vowel symbols to be used for Quechuan. Whereas Peruvian university linguists advocated the use of three vowels 
$(a, i, u)$, SIL and the Academia Mayor de la Lengua Quechua favored the use of five vowels $(a, e, i, o, u)$, keeping the orthography of Quechuan dialect varieties closer to that of Spanish.

The issue underlying this controversy is that Quechuan and Aymaran languages originally distinguish only three vowel phonemes $(a, i, u)$. In the neighborhood of an uvular consonant, represented by the symbol $q$ in most modern orthographies, the high vowels $i$ and $u$ are automatically lowered to mid position, becoming [e] $\sim[\varepsilon]$ and [o] [0], respectively. In Quechuan varieties such as Ecuadorian Quechuan and the variety spoken in the province of Huancayo in central Peru, this lowering became undone as the uvular articulation was lost, thus showing the strength of the underlying trivocalic system. In present-day Quechuan varieties, the non-conditioned mid vowels $e$ and $o$ are frequently found in borrowings from Spanish. Most of these varieties also feature a few instances of mid vowels that are not entirely predictable by the environment in which they occur (at morpheme boundaries and in onomatopoeic expressions, for instance). An additional cultural factor favoring a pronunciaton-based orthography with five vowels may be that its defenders consider a three-vowel system to be inferior to the five-vowel system associated with the dominant Spanish language.

Divergent orthographic choices are especially noticeable between the different languages spoken in the Andean region. Whereas Brazilian and Colombian linguists favor the use of the International Phonetic Alphabet, ethnic groups located in or near the Andean region tend to develop their own spellings, which can easily develop into a sort of identity marker for the language community in question. Mainstream orthographies for Quechuan and Aymaran may even differ on points where the languages show identical behavior. Smaller language communities with idiosyncratic spelling conventions are the Bora, the Cofan, the Jaqaru and the Moseten. Such spellings are also used in linguistic literature at some cost for cross-linguistic transparency.

Linguistic purism and language engineering have become everyday phenomena within many South American indigenous speech communities. Samples of folk literature and educational texts published in Quechuan and Aymaran languages generally have a much lower incidence of Spanish loans than tends to be the case in spoken conversation, showing that such loans are consciously avoided. At a meeting entitled As linguas indigenas da Amazonia na ciencia e nas sociedades

\section{camp_001.pod 23}


07-10-06 13:07:39 -mu- mu

Historical overview 23

('The indigenous languages of Amazonia in science and in the societies'), organized at the Museu Paraense Emilio Goeldi in Belem in March 1996 (cf. Queixalos and Renault Lescure 2000), a representative of the Shuar nation from Ecuador reported on the efforts of his community to expand the native vocabulary in regular sessions dedicated to the selection of new words, such as names for numbers, weekdays and months. In this way, a newly coined Shuar term for "eight" was chosen that was identical to the word for "ant" because of the similarity in appearance between the insect and the Arabic symbol representing that number. (For a case study of language revitalization among the Shuar see Grenoble and Whaley [2006: 78-86].) Bora communities in the border area of Colombia and Peru have been reported to discuss the acceptability of specific nominal classifiers in their language in community meetings (Thiesen and Weber, forthcoming).

\section{Bilingual education programs of the 1980 s and their side-effects}

Since the 1960s, there have been efforts to introduce South American indigenous languages in formal education by the development of teaching materials as well as bilingual programs. Such activities have had a lasting influence on linguistic studies related to the Andean region in particular. One of the first experimental programs aiming to incorporate a variety of Quechuan in bilingual education operated in Quinua near Ayacucho (Peru) between 1964 and 1968 (Zuniga and Carrasco 1978). The recognition of Quechua as an official language in Peru did not lead to a lasting intervention of the state in educational matters involving the indigenous languages. Instead, internationally financed programs took over the initiative, in particular after 1980. An experimental project of bilingual education, known as Proyecto Experimental de Educacion Bilingue de Puno (PEEB-P), co-financed by the German Society for Technical Cooperation (GTZ), was established in Puno (Peru) and operated between 1978 and 1990. This project was aimed at the Aymara and Puno Quechua speaking communities of the Altiplano. Its influence was significant both in Peru and Bolivia, and it stimulated all sorts of publication activities, including dictionaries, collections of folk literature, teaching materials and text books. It also brought research opportunities for local and foreign linguists and enabled native speakers to write down and publish their traditions. In a sociolinguistic evaluation of this project Hornberger (1998) reports on speaker attitudes that limit the effect of bilingual schooling upon language maintenance in the 
Andes. External political tensions affected the PEEB project in its final stage. However, a similar project initiated in Ecuador in 1985, called Programa de Educacion Bilingue Intercultural ( $P E B I)$, appears to have a lasting effect on language maintenance in the Ecuadorian highlands, because it has the support of a powerful indigenous organization, the Confederacion de Nacionalidades Indigenas del Ecuador (CONAIE). Like PEEB, PEBI has produced a considerable spin-off in

\section{camp_001.pod 24}

\section{7-10-06 13:07:39 -mu- mu}

\section{Willem F. H. Adelaar}

publications. The addition of the epithet "Intercultural" emphasizes the bidirectional character of bilingual education, which is no longer envisioned in the present societal context as a means to transfer knowledge from one culture to another. The situation of language contact involving Spanish and Quechua in the Ecuadorian highlands has been studied by Buttner (1993) and by Haboud (1998). In the southern part of the Andean region a new internationally financed program has taken the lead since 1996, Programa de Formacion en Educacion Intercultural Bilingue para los Paises Andinos (PROEIB Andes). PROEIB Andes has its headquarters in Cochabamba, Bolivia, and has become very influential through its conferences, the courses it offers to indigenous educators and its well-informed online bulletin. Although mainly focusing on Bolivia, PROEIB Andes also offers courses to indigenous people from other countries, for instance, to Mapuche educators from Chile.

\section{Linguistic typology and endangered languages: The breakthrough of the 1990s}

About 1990 the state of documentation of the indigenous languages of South America still left much to be desired. In-depth grammars of individual languages were scarce, and there were few indications that an improvement of the situation was forthcoming. Surprisingly but fortunately, research activity focusing on the indigenous languages of South America proliferated during the 1990s and soon attained an unprecedented level of volume and success. At present (2011) the amount of accessible data and descriptive materials that are available to the linguistic community is rich and varied. Much of it has been published or is in the process of being published by renowned editors. There are but few languages left that remain totally untouched by research. Most important of all, the interaction and communication between linguists working on different languages in different parts of South America has improved dramatically. 
Two developments contributed in particular to the success of South American Indian linguistics in the 1990s and 2000s. They are the increased interest for language typology and the rise of the endangered languages movement. The search for language types benefits from an ample display of data, in which all possible features of language must be represented, including the most exotic ones (see Campbell, this volume). It stimulates a focused attention on language diversity, rather than on efforts to find a common denominator valid for all languages, as had been the concern of earlier linguistic currents. The expansion of typological research depends on the kind of new data that can only be obtained in the field or in archives from poorly documented languages representing unfamiliar language types. South America with its extreme typological and genetic diversity and its unique features, such as nasal contours, Amazonian classifiers, evidentials and objectinitial constituent order, turned out to be an ideal terrain for field research, able

\section{camp_001.pod 25}

\section{7-10-06 13:07:39 -mu- mu}

Historical overview 25

to satisfy the demand for undiscovered data from the international community of language typologists. As a result, South American languages, virtually unknown a few decades ago, are now well represented in linguistic literature. Many language typologists participate in the activities of the Association for Linguistic Typology $(A L T)$. A center for typological research that has been particularly active in the field of South American linguistics is the Research Center of Linguistic Typology (RCLT), headed by R. M. W. Dixon and A. Y. Aikhenvald (until 2008), at La Trobe University, Melbourne.

The endangered languages movement started in the early 1990s through an initiative of concerned linguists alarmed by the ever increasing extinction rate of the world's languages. Areas of extreme linguistic diversity, such as South America, where all indigenous languages are endangered or potentially endangered, are disproportionately affected by this process (see Crevels, this volume).

As a result of the massive extinction of languages, the science of linguistics is losing an essential and irreplaceable part of its empirical basis, not to mention the historical and cultural riches that are lost with the death of each undocumented language. For small societies, as well as for the outside world, language is also an important ethnic identity marker, whose disappearance directly affects the chances 
of recognition and survival of the speaker group.

In 1992, the endangered languages problem was discussed in a plenary forum on the occasion of the 15th International Congress of Linguists in Quebec City. During a preparatory meeting at the UNESCO headquarters in Paris, two unclassified South American languages were singled out as priority items for documentary field research. One of these languages was the highly endangered and practically undocumented Koaia language isolate, spoken in a mixed community in the state of Rondonia, Brazil, together with Aikana or Huari (unclassified), and Latunde (Nambikwaran). Subsequently, Koaia (now renamed Kwaza), a language of c. 25 speakers, most of whom are also fluent in Aikana and Portuguese, became the subject of a project resulting in one of the most detailed linguistic descriptions of any South American language to date (van der Voort 2004). In the following years, UNESCO supported more initiatives such as the publication of an Atlas of the World's Languages in Danger of Disappearing (Wurm 1996). The latest edition of this work, to which linguists from South America and other parts of the world contributed, includes both a version on paper (Moseley 2010) and an interactive online version (Moseley 2009). ${ }_{3}$ Another initiative of UNESCO was the establishment at Tokyo University of an International Clearing House for Endangered Languages (ICHEL), which harbored an online Red Book of Endangered Languages with situation reports on endangered South American languages collected by Mily Crevels (operational between 1995 and 2009). Furthermore, UNESCO granted the oral traditions and language of the nearly extinct Zaparo of the Ecuadorian and Peruvian Amazon the status of "Masterpiece of the Oral and Immaterial Patrimony of Humanity" in 2001.

\section{camp_001.pod 26}

\section{7-10-06 13:07:39 -mu- mu}

\section{Willem F. H. Adelaar}

Since the first initiatives of the endangered languages movement several specialized publications that dedicate substantial chapters to the South American situation have appeared (Robins and Uhlenbeck 1991; Grenoble and Whaley 1998; Queixalos and Renault-Lescure 2000; Brenzinger 2007). More importantly, several international funding agencies have initiated funding programs supporting the description and documentation of endangered languages. Research on South American native languages has benefited considerably from these programs. The 
two most influential international programs are that of the Volkswagen Foundation in Hanover, Germany, and that of the Hans Rausing Endangered Languages Project hosted by the School of African and Oriental Studies (SOAS) in London. The Volkswagen Foundation program is notable for its emphasis on integral language documentation, including both linguistic and extra-linguistics aspects of language use. It subsidizes the Documentation of Endangered Languages program (DoBeS) hosted by the Max Planck Institute in Nijmegen (Netherlands), which provides advanced storage facilities for documentary language data generated by the field projects of the Volkswagen Foundation (including several projects on languages of Argentina, Bolivia, and Brazil). In addition, funding agencies operating at a national level have also initiated endangered languages programs that benefit descriptive and documentary research in South America (for instance, the National Science Foundation (NSF) and the National Endowment for the Humanities (NEH) in the USA, the Netherlands Organisation for Scientific Research (NWO) in the Netherlands). Research on endangered languages of South America is actively supported by many institutions, such as Centre National de la Recherche Scientifique (CNRS) in France, the University of Oregon at Eugene, the University of Texas at Austin, the University of California at Santa Barbara, and the Center for American Indian Languages (CAIL) at the University of Utah. Several specialized journals, in particular, International Journal of American Linguistics (Chicago) and Anthropological Linguistics (Bloomington) in the USA, as well as LIAMES (Campinas) and Revista Brasileira de Linguistica Antropologica (Brasilia) in Brazil, Amerindia (Paris) in France and UniverSoS (Valencia) in Spain, regularly publish the results of research conducted on the indigenous languages of South America. The online Newsletter of the Society for the Study of Indigenous Languages of the Americas (SSILA) provides information on ongoing activities and new publications.

The greatest surprise, without any doubt, is the rise of Amerindian linguistics in Brazil, which has turned that country from one of the linguistically least studied places in the Americas to one of the most dynamic areas of research in just a few years. In the 1980s, there were few universities or research centers in Brazil that paid attention to the indigenous languages, most of which were undescribed and dying out. Only one university, that of Campinas (UNICAMP) in the state of Sao Paulo, had a chair for indigenous languages. In other universities, students often wrote preliminary papers on the phonology of American Indian languages but were not encouraged to enter the field beyond that. At present, American Indian linCamp_ 


\section{1.pod 27}

\section{7-10-06 13:07:39 -mu- mu}

Historical overview 27

guistics in Brazil is flourishing, where young local linguists, as well as foreign researchers, co-operate in a highly productive symbiosis. More than ten institutions participate actively in research activities directed at the indigenous languages of the country, among which the Museu Paraense Emilio Goeldi in Belem (where the linguistics program is headed by Denny Moore), the University of Brasilia, the University of Rio de Janeiro, the University of Pernambuco in Recife and the University of Campinas must be mentioned in particular. The surviving Brazilian languages are being described and documented systematically with only few exceptions. Also with respect to Brazil, the historical-comparative approach to the study of indigenous languages has been more successful than elsewhere. The appreciation of the indigenous languages, both from the side of the speakers and from the side of the national society and the outside world in general, has improved over the last two decades. Programs for language maintenance and revitalization are arising among many native groups in the country. In recent years several important studies of Brazilian languages have been published: Taylor on Baniwa (1991); Aikhenvald (1995) on Bare; Everett and Kern (1997) on Wari' (Pacaas Novos); Ramirez (1997) on Tukano; Seki (2000) on Kamaiura; Aikhenvald (2003) on Tariana; Cabral and Rodrigues (2003) on Asurini do Tocantins; Dixon (2004) on Jarawara; van der Voort (2004) on Kwaza; Ferreira (2005) on Parkateje; and Epps on Hup (2008). Area typology and language contact in a complex multilingual area in northwestern Brazil is treated in Aikhenvald (2002). Several books deal with theoretical issues related to Brazilian languages (Everett 1991; Wetzels 1995). Among the many dissertations on Brazilian languages that have been defended in recent years we may mention Faco Soares (1992) on Tikuna; Ramirez (1994) on Yanomami; Reis Rodrigues (1995) on Xipaya; Sandalo (1995) on Kadiweu; Gabas (1999) on Karo; Guirardello on Trumai (1999); Storto (1999) on Karitiana; Meira (1999) on Tiriyo; Pacheco (2001) on Ikpeng; Facundes (2000) on Apurina; Vilacy (2001) on Mekens; Dourado (2001) on Panara; Angenot de Lima (2002) on More; Stenzel (2004) on Wanano; Bacelar (2004) on Kanoe; Braga (2005) on Makurap; Silva Juliao (2005) on Anambe; Sousa Cruz (2005) on Ingariko; Tavares (2005) on Wayana; Dienst (2006) on Culina; dos Anjos (2011) on Katukina and da Cruz 
(2011) on Nheengatu. In addition, two projects headed by W. L.Wetzels at the Free University of Amsterdam that are dedicated to the Nambikwara and Maku-Puinave language families have generated several descriptive studies: Telles (2002) on Latunde; Antunes (2004) on Sabane, Andrade Martins (2004) on Daw; and Eberhard (2009) on Mamainde.

Another South American country that has received more than average attention from descriptive linguists in recent years is Bolivia. A meticulous survey of the distribution of the indigenous languages in Bolivia with highly specific maps is Albo (1995). A specialized program for the languages of the Bolivian lowlands headed by P. C. Muysken of the University of Nijmegen has generated outstanding grammars of Movima (Haude 2006), Yuracare (van Gijn 2006) and Baure (DanielCamp_

\section{1.pod 28}

\section{7-10-06 13:07:39 -mu- mu}

\section{Willem F. H. Adelaar}

sen 2007). Detailed grammars have appeared of Moseten (Sakel 2004) and Cavinena (Guillaume 2008). A comparative study of the available sources on the Uru or Uchumataqu language of Iruito in Bolivia can be found in Hannß (2008). Novelties in relation to the highland languages are Cerron-Palomino's books on the Chipaya language of the Bolivian Altiplano (Cerron-Palomino 2006) and on Andean onomastics (Cerron-Palomino 2008). Several in-depth studies of Quechuan (Hintz 2007, Hintz 2008) and Aymaran varieties (Coler-Thayer 2010), as well as new approaches to reconstructive work (Heggarty 2005), indicate a renewed interest in Andean linguistics.

For the non-Andean languages of Peru and Ecuador several important contributions should be mentioned: Cabral (1995) on Cocama; Gnerre (1999) on Shuar; Dickinson (2002) on Tsafiki; Valenzuela (2003) on Shipibo-Conibo; Fleck (2003) on Matses; Olawsky (2006) on Urarina; Michael (2008) on Nanti; Overall (2007) on Aguaruna; and Zariquiey (2011) on Kashibo-Kakataibo. There are good surveys of the languages of Peru in Pozzi-Escot (1998) and Chirinos (2001). The rich research tradition of the Argentinian descriptive linguists has been continued through numerous new publications covering languages from both Argentina and Paraguay and including grammars of Maka (Gerzenstein 1994), Tehuelche (Fernandez Garay 1998), Mocovi (Grondona 1998; Gualdieri 1998), Pilaga (Vidal 2001), Toba (Messineo 2003), Tapiete (Gonzalez 2005) and Wichi, 
formerly called Mataco (Terraza 2008). An overview of the Argentinian languages is given in Censabella (1999). Mapuche varieties spoken in Argentina are treated or discussed in Fernandez Garay (2001, 2002) and Golluscio (2006). In Chile, the study of indigenous languages has mainly been concentrated on Mapuche (Salas 1992a, 1992b; Zuniga 2000; Smeets 2008) and Kawesqar (Aguilera 2001). A major lexicographic enterprise is the Atlas Linguistico Guarani-Romanico, conducted at the universities of Kiel and Munster in Germany (Dietrich and Symeonidis 2009). In connection with the languages of Colombia several important contributions can be mentioned, such as Curnow (1997) on Awa Pit (Cuaiquer); Queixalos (1998, 2000) on Sikwani (Guahibo); Rojas Curieux (1998) on Paez; Mortensen (1999) and Aguirre (1999) on Embera; Trillos (1999) on Damana; Seifart (2005) on Mirana; and Giron Higuita (2008) on Wansojot (Puinave). For the languages of Venezuela we may refer to the work of Alvarez (1994) on Guajiro; Mattei-Muller (1994) on Panare; Romero-Figueroa (1997) on Warao; and, last but not least, the collection of grammatical sketches in Mosonyi and Mosonyi (2000).

The languages of the Guyanas have been the object of active research since the 1990s. Among recent work we can mention Launey (2003) on Palikur, Rose (2011) on Emerillon, Carlin (2004) on Trio, and Courtz (2008) on Carib. A survey of the languages of Suriname, both native Indian and non-indigenous, can be found in Carlin and Arends (2002).

Linguistic description based on the interpretation of pre-modern materials is gradually gaining importance. In this context we can mention Zamponi's work on

\section{camp_001.pod 29}

\section{7-10-06 13:07:39 -mu- mu}

Historical overview 29

Betoi (Zamponi 2003a) and Maipure (Zamponi 2003b); Hovdhaugen (2004) on Mochica; Salas' dictionary of that same language (Salas 2002); Alexander-Bakkerus' (2005) reconstruction of Cholon; Ostler's reconstructive work on the Muisca language and its closest relatives (Ostler 1994, 2000); and an edition of Antonio Machoni's grammar and dictionary of the Lule-Tonocote language with an extensive grammatical introduction by Raoul Zamponi (Maccioni 2008).

For some of the well established language families there has been significant progress in the establishment of internal relations. For the Cariban languages we may mention work by Gildea (1998), Meira (2000), Franchetto and Meira (2005); 
for Tupi-Guaranian: Dietrich (1990), Cabral (1995), Rodrigues and Dietrich (1997), Schleicher (1998), Jensen (1999) and Dietrich and Symeonidis (2006); for Macro-Jean: Ribeiro (2002, 2004); for possible relations connecting these three groups: Rodrigues (2000). For the Arawakan languages there has been important work by Payne (1991) and Ramirez (2001); for eastern Makuan: Martins (2005); for the languages of Argentina and adjacent areas Viegas Barros $(2001,2005)$. For a fuller treatment of advances in the historical-comparative linguistics of indigenous South America see Campbell, classification this volume.

Current research on the South American Indian languages can rely on a bibliographical tool developed by Fabre (1998). The published version of Fabre's highly useful Manual de las lenguas indigenas sudamericanas ('Manual of the South American indigenous languages') is regularly updated in online versions.

\section{Prospects}

Thanks to the developments of the past two decades the South American indigenous languages have finally attained their legitimate place on the stage of modern linguistics. There is no reason to assume that the trend towards full-scale documentation and grammatical description of the last unstudied languages of the South America will decrease. On the other hand, it will not be sufficient to have a single description for each language. Many of the older descriptions, especially those of the Andean languages, were written in a time in which formal approaches predominated and functionalist views, semantic refinement and syntactic analysis had not yet reached their present potential. There will almost certainly be a call to modernize most of the work on the Aymaran and the Quechuan families that was written in the 1970s and 1980s. The same holds for some of the earlier grammars and dictionaries of South American Indian languages produced by SIL, which were often sketchy and incomplete.

A field that has been showing signs of a take-off is South American historicalcomparative linguistics. The genetic situation of the Amazonian languages is gradually becoming more transparent. In contrast, progress in historical linguistics concerning the languages of the Pacific side of South America and the eastern

\section{camp_001.pod 30}

\section{7-10-06 13:07:39 -mu- mu}

\section{Willem F. H. Adelaar}

slopes of the Andes remains unsatisfactory for the time being. The area of the Gran Chaco, where the languages of the Lengua-Mascoyan and Zamucoan families have 
not been sufficiently studied, also still defies attempts at classification. In the meantime, language contact studies and typological studies will contribute to a better understanding of the complex relations that exist (and have always existed) between the native languages of South America. Finally, the possible linguistic relations between South America, on one hand, and Mesoamerica and North America, on the other, will have to be addressed. Language maintenance, revitalization and language standardization will remain important issues in the years to come. The eventual survival of any of the South American Indian languages cannot be taken for granted, and depends on the willingness of the speaker communities to invest in language maintenance. The outcome of all the efforts to keep the languages alife is far from certain.

\section{Notes}

1 The Amerindian languages section of Leiden University is preparing an edition of Natterer's wordlists.

2 Caspar's unpublished material on the languages of Rondonia has been digitized and partly transcribed at Leiden University. It can be accessed on the Digital Humanities site of the Leiden University Library (https://digihum.leidenuniv.nl/amazonianlanguages).

3 http://www.unesco.org/culture/languages-atlas/

\section{References}

Abreu, Joao Capistrano de

1941 Ra-txa hu-ni-ku-i: a lingua dos Caxinauas do rio Ibuacu, affluente do Muru

(Prefeitura de Tarauaca). Rio de Janeiro: Sociedade Capistrano de Abreu and

Livraria Briguiet. First published Rio de Janeiro: Typographia Leuzinger

[1914].

Academia Mayor de la Lengua Quechua

2005 Diccionario: Quechua-Espano1-Quechua, Qheswa-Espano-Qheswa: Simi Taqe

(2nd edition). Cuzco: Academia Mayor de la Lengua Quechua.

Adam, Lucien

1893 Principes et dictionnaire de la langue Yuracare ou Yurujure composes par

le R. P. de la Cueva et publies conformement au manuscript de A. d'Orbigny.

(Bibliotheque linguistique americaine 16.) Paris: Maisonneuve.

Adam, Lucien and Victor Henry

1880 Arte y vocabulario de la lengua Chiquita con algunos textos traducidos y explicados compuestos sobre manuscritos ineditos del siglo XVIII. (Bibliotheque

linguistique americaine 6.) Paris: Maisonneuve.

\section{camp_001.pod 31}

\section{7-10-06 13:07:39 -mu- mu}


Historical overview 31

Adam, Lucien and Charles Leclerc

1878 Grammaire caraibe composee par le Pere Breton, suivie de catechisme

caraibe. Paris: Maisonneuve.

Adelaar, Willem F. H.

1977 Tarma quechua. Grammar, Texts, Dictionary. Lisse: Peter de Ridder.

Adelaar, Willem F. H.

1987 Morfologia del Quechua de Pacaraos. Lima: Facultad de Letras y Ciencias Humanas,

Universidad Nacional Mayor de San Marcos. (Also pubished as CILA

Document 53, Lima: Universidad Nacional Mayor de San Marcos [1986].)

Adelaar, Willem F. H.

1991 The endangered languages problem: South America. In: R. H. Robins and E. M.

Uhlenbeck (eds.), Endangered Languages, 45-91. Oxford, New York: Berg

Adelaar, Willem F. H.

2000 Propuesta de un nuevo vinculo genetico entre dos grupos linguisticos indigenas

de la Amazonia occidental: Harakmbut y Katukina. In: L. Miranda Esquerre

(ed.), Actas I Congreso de Lenguas Indigenas de Sudamerica (Lima,

August 1999), Volume 2, 219-236. Lima: Universidad Ricardo Palma, Facultad

de Lenguas Modernas.

Adelaar, Willem F. H.

2006 The Quechua impact in Amuesha, an Arawak language of the Peruvian Amazon.

In: A. Y. Aikhenvald and R. M. W. Dixon (eds.), Grammars in Contact.

A Cross-Linguistic Typology, 290-312. Oxford: Oxford University Press.

Adelaar, Willem F. H.

2008 Relacoes externas do Macro-Je: O caso do Chiquitano. In: Stella Telles and

Aldir Santos de Paula (eds.), Topicalizando Macro-Je, 9-28. Recife: Nectar.

Adelaar, Willem F. H., with the collaboration of Pieter C. Muysken

2004 The Languages of the Andes. Cambridge: Cambridge University Press. (Revised

paperback edition 2007.)

Adelung, Johann Christoph and Johann Severin Vater

1806-1817 Mithridates, oder allgemeine Sprachenkunde, mit dem Vater Unser als

Sprachprobe in beynahe funf hundert Sprachen und Mundarten. Berlin: Vossische

Buchhandlung.

Aguilera Faundez, Oscar

2001 Gramatica de la lengua kawesqar. Temuco: Corporacion de desarrollo indigena.

Aguirre Licht, Daniel

1999 Embera. Munich, Newcastle: LINCOM Europa.

Aikhenvald, Alexandra Y.

1995 Bare. Munich, Newcastle: LINCOM Europa. 
Aikhenvald, Alexandra Y.

2002 Language Contact in Amazonia. Oxford: Oxford University Press.

Aikhenvald, Alexandra Y.

2003 A Grammar of Tariana, from Northwest Amazonia. Cambridge: Cambridge

University Press.

Albo, Xavier

1995 Bolivia plurilingue. Guia para planificadores y educadores. La Paz: UNICEF, CIPCA.

\section{camp_001.pod 32}

\section{7-10-06 13:07:39 -mu- mu}

32 Willem F. H. Adelaar

Alderetes, Jorge R.

2001 El quechua de Santiago del Estero. Gramatica y vocabulario. Tucuman: Universidad Nacional de Tucuman, Facultad de Filosofia y Letras.

Alexander-Bakkerus, Astrid

2005 Eighteenth Century Cholon. Utrecht: Netherlands Graduate School of Linguistics (LOT).

Allin, Trevor R.

1976 A Grammar of Resigaro. Horsleys Green, High Wycombe, Bucks.: Summer Institute of Linguistics.

Alvarez, Jose

1994 Estudios de linguistica guajira. Maracaibo: Gobernacion del Estado Zulia, Secretaria de Cultura.

Anchieta, Joseph de

1946 Arte de grammatica da lingua mais usada na costa do Brasil. Sao Paulo: Editora

Anchieta. First published Coimbra: Antonio Mariz [1595].

Andrade Martins, Silvana

2004 Fonologia e Gramatica Daw. Utrecht: Netherlands Graduate School of Linguistics

(LOT).

Angenot-de Lima, Geralda

2002 Description phonologique, grammaticale et lexicale du more, langue amazonienne de Bolivie et du Bresil. Guajara-Mirim: Editora da Universidade Federal

de Rondonia.

Anjos, Zoraide de

2011 Fonologia e gramatica katukina-kanamari. Utrecht: Netherlands Graduate

School of Linguistics (LOT).

Antunes de Araujo, Gabriel

2004 A Grammar of Sabane, a Nambikwaran Language. Utrecht: Netherlands Graduate 
School of Linguistics (LOT).

Aschmann, Richard P.

1993 Proto-Witotoan. Arlington: SIL and University of Texas at Arlington.

Augusta, Felix Jose de

1966 Diccionario Araucano. Tomo Primero: Araucano-Espanol. Padre las Casas:

Editorial "San Francisco". First published [1916].

Augusta, Felix Jose de

1990 Gramatica araucana. Santiago de Chile: Ediciones Seneca. First published

Valdivia: Imprenta Lampert [1903].

Augusta, Felix Jose de

1991 Diccionario Espanol-Mapuche. Santiago de Chile: Ediciones Seneca. First

published [1916].

Baarle, Peter van

1999 Eighteenth century descriptions of Arawak by Moravian missionaries. In:

E. Nowak (ed.), Languages Different in All their Sounds: Descriptive Approaches

to Indigenous Languages of the Americas 1500 to 1850,117-54.

Munster: Nodus.

Baarle, Peter van, M. A. Sabajo, A. L. Sabajo, L. L. Sabajo and G. vander Stap

1989 Arhwaka Lokonong Djang. Arawakse taalkursus en woordenboek. [Arawakan

language and dictionary]. Haarlem: Sociaal-culturele Vereniging "Ikyoshie".

Amsterdam: University of Amsterdam, Institute of General Linguistics.

\section{camp_001.pod 33}

\section{7-10-06 13:07:39 -mu- mu}

Historical overview 33

(French version translated by M. F. Patte, Manuel de langue arawak. Paris:

Editions du Saule [1997].)

Bacelar, Laercio Nora

2004 Gramatica da lingua kanoe. Ph.D. dissertation, Radboud University Nijmegen.

Bertonio, Ludovico

1603 Arte breve de la lengua aymara para introduccion del arte grande de la misma

lengua. Rome: Luigi Zanetti.

Bertonio, Ludovico

1879 Arte y grammatica muy copiosa de la lengua aymara. Leipzig: Teubner. First published Rome: Luigi Zanetti [1603].

Bertonio, Ludovico

1984 Vocabulario de la lengua aymara. Cochabamba: CERES, IFEA, MUSEF. First

published Juli, Chucuito: Francisco del Canto [1612].

Betanzos, Juan de 
1987 Suma y narracion de los Incas. Edited by Maria del Carmen Martin Rubio.

Madrid: Atlas. First published [1551].

Braga, Alzerinda de Oliveira

2005 Aspects morphosyntaxiques de la langue makurap/tupi. Ph.D. dissertation,

Toulouse, Le Mirail.

Bravo, Domingo A.

1956 El quichua santiagueno (reducto idiomatico argentino). Tucuman: Ministerio de Educacion de la Nacion, Universidad Nacional de Tucuman, Facultad de

Filosofia y Letras.

Brenzinger, Matthias (ed.)

2007 Language Diversity Endangered. New York/Berlin: Mouton de Gruyter.

Breton, Raymond

1999 Dictionnaire caraibe-francois. Paris: Editions Karthala. First published Auxerre [1665].

Breton, Raymond

1900 Dictionnaire francois-caraibe. Leipzig: J. Platzmann. First published Auxerre [1666].

Bridges, Thomas

1933 Yamana-English: A Dictionary of the Speech of Tierra del Fuego. Edited by

D. Hestermann and M. Gusinde. Modling near Vienna: Verlag der Internationalen

Zeitschrift "Anthropos”. Manuscript [1879].

Briggs, Lucy Therina

1976 Dialectal variation in the Aymara language of Bolivia and Peru. Ph.D. dissertation, University of Florida, Gainesville.

Briggs, Lucy Therina

1993 El idioma aymara: Variantes regionales y sociales. La Paz: Ediciones ILCA.

Brinton, Daniel Garrison

1891 The American Race: A Linguistic Classification and Ethnographic Description of the Native Tribes of North and South America. New York: Hodges.

Buttner, Thomas Th.

1983 Las lenguas de los Andes centrales. Estudios sobre la clasificacion genetica, areal y tipologica. Madrid: Ediciones Cultura Hispanica del Instituto de Cooperacion Iberoamericana.

\section{camp_001.pod 34}

\section{7-10-06 13:07:39 -mu- mu}

\section{Willem F. H. Adelaar}

Buttner, Thomas Th.

1993 Uso del quichua y del castellano en la sierra ecuatoriana. Quito: Abya-Yala. 
Cabral, Ana Suelly Arruda Camara

1995 Contact-induced language change in the western Amazon: The non-genetic

origin of the Kokama language. Ph. D. dissertation, University of Pittsburgh.

Cabral, Ana Suelly Arruda Camara and Aryon Dall'Igna Rodrigues

2003 Dicionario Asurini do Tocantins-Portugues. Belem: Universidade Federal do

Para.

Cadogan, Leon

1959 Ayvu rapyta: Textos miticos de los Mbya-Guarani del Guaira. (Boletim

227, Antropologia 5.) Sao Paulo: Universidade de Sao Paulo, Faculdade de

Filosofia, Ciencias e Letras. (New edition by CEADUC-CEPAG, Asuncion

[1992].)

Campbell, Lyle

1997 American Indian Languages: The Historical Linguistics of Native America.

Oxford: Oxford University Press.

Carlin, Eithne B.

2004 A Grammar of Trio: A Cariban Language of Suriname. Frankfurt am Main:

Peter Lang.

Carlin, Eithne B. and Jacques Arends

2002 Atlas of the Languages of Suriname. Leiden: KITLV Press.

Carrera Daza, Fernando de la

1939 Arte de la lengua yunga. Tucuman: R. A. Altieri, Universidad de Tucuman,

Instituto de Antropologia. First published [1644].

Carson, Neusa M.

1982 Phonology and Morphology of Makuxi (Carib). Ph. D. dissertation, University

of Kansas.

Casamiquela, Rodolfo

1983 Nociones de gramatica del Gununa Kune. Paris: Editions du CNRS.

Celedon, P. Rafael

1878 Gramatica, catecismo i vocabulario de la lengua goajira. (Bibliotheque linguistique americaine 5.) Paris: Maisonneuve.

Celedon, P. Rafael

1886 Gramatica de la lengua koggaba, con vocabularios y catecismos, y un vocabulario, espanol, chimila, guamaka y bintukua. (Bibliotheque linguistique americaine

10.) Paris: Maisonneuve.

Censabella, Marisa

1999 Las lenguas indigenas de la Argentina. Una mirada actual. Buenos Aires: Editorial

Universitaria de Buenos Aires.

Cerron-Palomino, Rodolfo M.

1976a Gramatica quechua Junin-Huanca. Lima: Ministerio de Educacion, Instituto 
de Estudios Peruanos.

Cerron-Palomino, Rodolfo M.

1976b Diccionario quechua Junin-Huanca. Lima: Ministerio de Educacion, Instituto de Estudios Peruanos.

Cerron-Palomino, Rodolfo M.

1987 Linguistica quechua. Cuzco: Centro "Bartolome de Las Casas".

\section{camp_001.pod 35}

\section{7-10-06 13:07:39 -mu- mu}

Historical overview 35

Cerron-Palomino, Rodolfo M.

2000 Linguistica aimara. Cuzco: Centro "Bartolome de Las Casas".

Cerron-Palomino, Rodolfo M.

2006 El chipaya o la lengua de los hombres del agua. Lima: Fondo Editorial de la

Pontificia Universidad Catolica del Peru.

Cerron-Palomino, Rodolfo M.

2008 Voces del Ande: Ensayos sobre onomastica andina. Lima: Fondo Editorial de la Pontificia Universidad Catolica del Peru.

Chirinos Rivera, Andres

2001 Atlas linguistico del Peru. Cuzco, Lima: Centro "Bartolome de Las Casas", Ministerio de Educacion.

Clairis, Christos

1987 El Qawesqar: Linguistica fueguina, teoria y descripcion. Estudios filologicos.

(Anejo 12 [1985].) Valdivia: Universidad Austral de Chile, Facultad de Filosofia

y Humanidades.

Clastres, Pierre

1974 Le grand parler: Mythes et chants sacres des Indiens Guarani. Paris: Editions du Seuil.

Cobo, Bernabe

1890-1895 Historia del Nuevo Mundo. Sevilla: Rasco. First published [1653].

Cole, Peter

1982 Imbabura Quechua. Amsterdam: North-Holland.

Cole, Peter, Gabriella Hermon and Mario Daniel Martin

1994 Language in the Andes. Newark: University of Delaware, Latin American

Studies Program.

Coler-Thayer, Matthew L.

2010 A grammatical description of Muylaq' Aymara. Ph.D. dissertation, Free University of Amsterdam.

Constenla Umana, Adolfo 
1981 Comparative Chibchan phonology. Ph.D. dissertation, University of Pennsylvania,

Philadelphia.

Constenla Umana, Adolfo

1991 Las lenguas del Area Intermedia: introduccion a su estudio areal. San Jose:

Editorial de la Universidad de Costa Rica.

Cona, Pascual

1984 Testimonio de un cacique mapuche. Santiago: Pehuen.

Coombs, David, Heidi Coombs and Robert Weber

1976 Gramatica quechua San Martin. Lima: Ministerio de Educacion, Instituto de

Estudios Peruanos.

Courtz, Hendrik

2008 A Carib Grammar and Dictionary. Toronto: Magoria Books.

Cruz, Aline da

2011 Fonologia e gramatica do Nheengatu: a lingua falada pelos Bare, Warekena e

Baniwa. Utrecht: Netherlands Graduate School of Linguistics (LOT).

Curnow, Timothy J.

1997 A grammar of Awa Pit (Cuaiquer), an indigenous language of south-western

Colombia. Ph.D. dissertation, Australian National University, Canberra.

\section{camp_001.pod 36}

\section{7-10-06 13:07:39 -mu- mu}

\section{Willem F. H. Adelaar}

Curnow, Timothy J. and Anthony J. Liddicoat

1998 The Barbacoan languages of Colombia and Ecuador. Anthropological Linguistics

40 (3): 384-408.

Cusihuaman Gutierrez, Antonio

1976a Gramatica quechua Cuzco-Collao. Lima: Ministerio de Educacion, Instituto

de Estudios Peruanos. (Also published by Centro "Bartolome de Las Casas",

Cuzco [2001])

Cusihuaman Gutierrez, Antonio

1976b Diccionario quechua Cuzco-Collao. Lima: Ministerio de Educacion, Instituto

de Estudios Peruanos.

Danielsen, Swintha

2007 Baure, an Arawak language of Bolivia. Leiden: CNWS Publications.

Danielsen, Swintha

Forthcoming The argument encoding system in Baure and other Southern Arawakan languages.

In: Antoine Guillaume and Francoise Rose (eds.), Argument-coding

systems in Bolivian Amazonian languages. International Journal of American

Linguistics. 
Davis, Irvine

1968 Some Macro-Je relationships. International Journal of American Linguistics

34 (1): 42-47.

Dedenbach-Salazar Saenz, Sabine

2006 Quechua for Catherine the Great: Jose Joaquin Avalos Chauca's Quechua

vocabulary (1788). International Journal of American Linguistics 72 (2):

193-235.

Derbyshire, Desmond C.

1979 Hixkaryana. (Lingua Descriptive Series 1.) Amsterdam: North-Holland.

Derbyshire, Desmond C. and Geoffrey K. Pullum (eds.)

1986-1998 Handbook of Amazonian Languages. Volume 1 (1986); Volume 2 (1990);

Volume 3 (1991); Volume 4 (1998). Berlin/New York: Mouton de Gruyter.

Dickinson, Connie

2002 Complex predicates in Tsafiki. Ph.D. dissertation, University of Oregon,

Eugene.

Dienst, Stefan

2006 A grammar of Culina. Ph. D. dissertation, La Trobe University, Victoria, Australia.

Dietrich, Wolf

1986 El idioma chiriguano. Madrid: Ediciones Cultura Hispanica, Instituto de

Cooperacion Iberoamericana.

Dietrich, Wolf

1990 More Evidence for an Internal Classification of the Tupi-Guarani Languages.

Berlin: Gebr. Mann.

Dietrich, Wolf and Haralambos Symeonidis (eds.)

2006 Guarani y "Maweti-Tupi-Guarani" . Estudios historicos y descriptivos sobre una familia linguistica de America del Sur. Berlin: LIT.

Dietrich, Wolf and Haralambos Symeonidis

2009 Atlas Linguistico Guarani-Romanico. Volume 1: Lexico del cuerpo humano.

Kiel: Westensee Verlag.

\section{camp_001.pod 37}

\section{7-10-06 13:07:39 -mu- mu}

Historical overview 37

Dixon, R. M. W. with the assistance of Alan R. Vogel

2004 The Jarawara Language of Southern Amazonia. Oxford: Oxford University

Press.

Dixon, R. M. W. and Alexandra Y. Aikhenvald (eds.)

1999 The Amazonian Languages. Cambridge: Cambridge University Press.

Dourado, Luciana 
2001 Aspetos morfossintaticos da lingua Panara (Je). Ph. D. dissertation, University

of Campinas.

Eberhard, David M.

2009 Mamainde Grammar: a Northern Nambikwara Language and its Cultural

Context. Utrecht: Netherlands Graduate School of Linguistics (LOT).

Ehrenreich, Paul

1894 Materialien zur Sprachenkunde Brasiliens. Zeitschrift fur Ethnologie 26:

20-37, 49-60: Die Sprache der Caraya (Goyaz); 26:115-37: Die Sprache der

Caiapo (Goyaz).

Elson, Benjamin F.

1963 Studies in Peruvian Indian Languages. Volume 1. Norman: University of Oklahoma,

Summer Institute of Linguistics.

Epps, Patience

2008 A Grammar of Hup. Berlin/New York: Mouton de Gruyter.

Eschwege, Wilhelm L. Von

1818 Journal von Brasilien, oder vermischte Nachrichten aus Brasilien. Weimar:

Landes-Industrie-Comptoir.

Everett, Daniel L.

1991 A lingua piraha e a teoria da sintaxe: descricao, perspectivas e teoria. Campinas:

Editora da Unicamp.

Everett, Daniel L. and Barbara Kern

1997 Wari' . The Pacaas Novos Language of Western Brazil. London/New York:

Routledge.

Fabre, Alain

1998 Manual de las lenguas indigenas sudamericanas. Munich/Newcastle. LINCOM

Europa.

Faco Soares, Marilia

1992 O suprassegmental em Tikuna e a teoria fonologica. Ph.D. dissertation, University

of Campinas.

Facundes, Sidney da Silva

2000 The language of the Apurina people of Brazil (Maipure/Arawak). Ph. D. dissertation, University of New York, Buffalo.

Febres, Antonio

1975 Arte de la lengua general del reino de Chile. Vaduz/Georgetown: Ediciones

Cabildo. First published [1764].

Fernandez Garay, Ana V.

1998 El tehuelche: una lengua en vias de extinction. (Estudios filologicos, Anejo 15.)

Valdivia: Universidad Austral de Chile, Facultad de Filosofia y Humanidades.

Fernandez Garay, Ana V. 
2001 Ranquel-espanol espanol-ranquel, diccionario de una variedad mapuche de La Pampa (Argentina). Leiden: CNWS Publications.

\section{camp_001.pod 38}

\section{7-10-06 13:07:39 -mu- mu}

38 Willem F. H. Adelaar

Fernandez Garay, Ana V.

2002 Testimonios de los ultimos Ranqueles. Buenos Aires: Universidad de Buenos Aires, Facultad de Filosofia y Letras, Instituto de Linguistica.

Ferrario, Benigno

1956 La dialettologia ed i problemi interni della Runa-Simi (vulgo Quechua). Orbis

5: $131-40$.

Ferreira, Marilia

2005 Morfossintaxe da lingua Parkateje. Munich: LINCOM Europa.

Figueredo, Juan de

1964 Vocabulario de la lengua chinchaisuyo y algunos modos mas usados en dicha lengua. In: L. A. Pardo and C. Galimberti Miranda (eds.), Diego de Torres Rubio, Arte de la lengua quichua, 112-120. Cuzco: H. G. Rozas. First published [1700].

Fleck, David

2003 A grammar of Matses. Ph. D. dissertation, Rice University, Houston.

Franchetto, Bruna and Sergio Meira

2005 The southern Cariban languages and the Cariban family. International Journal

of American Linguistics 71 (2): 127-192.

Gabas, Nilson, Jr.

1999 A grammar of Karo. Ph.D. dissertation, University of California at Santa

Barbara.

Galeote Tormo, Jesus

1993 Manityana auki besiro. Gramatica moderna de la Lengua Chiquitana y vocabulario basico. Santa Cruz de la Sierra: Imprenta "Los Huerfanos".

Galucio, Ana Vilacy

2001 The morphosyntax of Mekens (Tupi). Ph.D. dissertation, University of Chicago.

Gerzenstein, Ana

1978-1979 Lengua chorote. Buenos Aires: Universidad de Buenos Aires, Instituto de Linguistica.

Gerzenstein, Ana

1994 Lengua maka: estudio descriptivo. Buenos Aires: Universidad de Buenos

Aires, Facultad de Filosofia y Letras, Instituto de Linguistica.

Gijn, Rik van

2006 A grammar of Yurakare. Ph.D. dissertation, Radboud University Nijmegen. 
Gildea, Spike L. O.

1998 On Reconstructing Grammar: Comparative Cariban Morphosyntax. Oxford:

Oxford University Press.

Gilij, Filippo Salvatore

1782 Saggio di storia Americana; o sia, Storia naturale, civile e sacra de' regni, e delle provincie spagnuole di Terra-ferma nell' America Meridionale. Volume 3:

Della religione, e delle lingue degli Orinochesi, e di altri Americani. Rome:

Luigi Perego.

Giron Higuita, Mario

2008 Una Gramatica del Wa’ nsojot (Puinave). Utrecht: Netherlands Graduate

School of Linguistics (LOT).

Gnerre, Maurizio

1986 The decline of dialogue: Ceremonial and mythological discourse among the

Shuar and Achuar. In: J. Sherzer and G. Urban (eds.), Native South American

Discourse, 307-341. Berlin/New York: Mouton de Gruyter.

\section{camp_001.pod 39}

\section{7-10-06 13:07:39 -mu- mu}

Historical overview 39

Gnerre, Maurizio

1999 Profilo descrittivo e storico-comparativo di una lingua amazzonica: lo

shuar (jivaro). Napoli: Istituto Universitario Orientale, Dipartimento di Studi

del Mondo Classico e del Mediterraneo Antico. Quaderni di Al_N, nuova

serie 1.

Goeje, Claudius H. de

1935 Funf Sprachfamilien Sudamerikas. Verhandelingen van de Koninklijke Akademie

van Wetenschappen-Afdeling Letterkunde 77 (Serie A, no. 5.) Amsterdam.

Golluscio, Lucia A.

2006 El pueblo mapuche: poeticas de pertenencia y devenir. Buenos Aires: Editorial

Biblos.

Gomez-Imbert, Elsa

1982 De la forme et du sens dans la classification nominale en tatuyo (Langue

Tukano Orientale d'Amazonie Colombienne). Ph.D. dissertation, Universite

Sorbonne-Paris IV.

Gonzales de Barcia Carballido y Zuniga, Andres

1737-1738 Epitome de la biblioteca oriental y occidental, nautica y geografica de Don Antonio de Leon Pinelo. Madrid: Francisco Martinez Abad.

Gonzalez, Hebe Alicia

2005 A grammar of Tapiete (Tupi-Guarani). Ph. D. dissertation, University of Pittsburgh. 
Gonzalez de Perez, Maria Stella

1987 "Diccionario y gramatica chibcha" : manuscrito anonimo de la Biblioteca Nacional

de Colombia. Bogota: Instituto Caro y Cuervo.

Gonzalez de Perez, Maria Stella and Maria Luisa Rodriguez de Montes

2000 Lenguas indigenas de Colombia: una vision descriptiva. Bogota; Instituto

Caro y Cuervo.

Gonzalez Holguin, Diego

1842 Gramatica y arte nueva de la lengua general de todo el Peru llamada lengua

qquichua o lengua del Inca. Genoa: Pagano. First published Lima: Francisco

del Canto [1607].

Gonzalez Holguin, Diego

1989 Vocabulario de la lengua general de todo el Peru llamada lengua qquichua o lengua del Inca. Lima: Universidad Nacional Mayor de San Marcos. First published

Lima: Francisco del Canto [1608].

Greenberg, Joseph H.

1959 Linguistic classification of South America. In: J. H. Steward and L. C. Faron

(eds.), Native Peoples of South America, 22-23. New York/Toronto/London:

McGraw-Hill.

Greenberg, Joseph H. 1960a

Linguistic classification of South America. In S. Tax (ed.), Aboriginal languages

of Latin America. Current Anthropology 1 (5-6): 431-436.

Greenberg, Joseph $\mathrm{H}$.

1960b The general classification of Central and South American languages. In:

A. Wallace (ed.), Men and Cultures: Selected Papers of the 5th International

\section{camp_001.pod 40}

\section{7-10-06 13:07:39 -mu- mu}

40 Willem F. H. Adelaar

Congress of Anthropological and Ethnological Sciences (1956), 791-4. Philadelphia:

University of Pennsylvania Press.

Greenberg, Joseph H.

1987 Language in the Americas. Stanford: Stanford University Press.

Gregores, Emma and Jorge A. Suarez

1967 A Description of Colloquial Guarani. The Hague / Paris: Mouton.

Grenand, Francoise

1980 La langue wayapi (Guyane francaise): phonologie et grammaire. Paris: SELAF.

Grenand, Francoise

1989 Dictionnaire wayapi-francais. Paris: SELAF and Editions Peeters.

Grenoble, Lenore A. and Lindsay J. Whaley (eds.) 
1998 Endangered Languages: Current Issues and Future Prospects. Cambridge:

Cambridge University Press.

Grenoble, Lenore A. and Lindsay J. Whaley

2006 Saving languages: An Introduction to Language Revitalization. Cambridge:

Cambridge University Press.

Grinevald, Colette

1998 Language endangerment in South America: A programmatic approach. In:

Lenore A. Grenoble and Lindsay J. Whaley (eds.), Endangered Languages:

Current Issues and Future Prospects, 124-159. Cambridge: Cambridge University

Press.

Grondona, Veronica Maria

1998 A grammar of Mocovi. Ph.D. dissertation, University of Pittsburgh.

Gualdieri, Cecilia Beatriz

1998 Mocovi (Guaicuru). Fonologia e morfossintaxe. Ph.D. dissertation, University

of Campinas.

Guasch, P. Antonio

1956 El idioma guarani: gramatica y antologia de prosa y verso. 3rd edition. Asuncion:

Casa America - Moreno Hermanos. (First published in 1944.)

Guasch, P. Antonio

1981 Diccionario castellano-guarani y guarani-castellano. 5th edition. Asuncion:

Ediciones Loyola.

Guerios, Rosario Farani Mansur

1945 Estudos sobre a lingua Camaca. Archivos do Museu Paranaense 4: 291-320.

Curitiba.

Guillaume, Antoine

2008 A Grammar of Cavinena. Berlin/New York: Mouton de Gruyter.

Guirardello, Raquel

1999 A reference grammar of Trumai. Ph.D. dissertation, Rice University, Houston.

Gusinde, Martin

1926 Das Lautsystem der feuerlandischen Sprachen. Anthropos 21: 1000-1024.

Gusinde, Martin

1931-1937 Die Feuerland-Indianer. Modling, Vienna: Verlag der internationalen

Zeitschrift "Anthropos".

Haboud, Marleen

1998 Quichua y castellano en los Andes ecuatorianos: Ios efectos de un contacto

prolongado. Quito: Abya-Yala.

\section{camp_001.pod 41}

07-10-06 13:07:39 -mu- mu 
Historical overview 41

Hannß, Katja

2008 Uchumataqu: The Lost Language of the Urus of Bolivia. A Grammatical Description of the Language as Documented between 1894 and 1952. Leiden:

CNWS Publications.

Hardman, Martha J.

1966 Jaqaru: Outline of Phonological and Morphological Structures. The Hague I

Paris: Mouton.

Hardman, Martha J.

1983 Jaqaru: compendio de estructura fonologica y morfologica. Lima: Instituto de

Estudios Peruanos.

Hardman, Martha J.

2000 Jaqaru. Munich: LINCOM Europe.

Hardman, Martha J., Juana Vasquez and Juan de Dios Yapita Moya

1974 Outline of Aymara Phonological and Grammatical Structure. Gainesville:

University of Florida.

Hardman, Martha J., Juana Vasquez and Juan de Dios Yapita Moya

1988 Aymara: compendio de estructura fonologica y gramatical. La Paz: Ediciones

ILCA; Gainesville: The Aymara Foundation.

Haude, Katharina

2006 A grammar of Movima. Ph.D. dissertation, Radboud University Nijmegen.

Havestadt, Bernardus

1777 Chilidugu sive res chilensis. Munster: Monasterii Westphaliae Typis Aschendorfianis.

[Second edtion by Julius Platzmann, 1883. Leipzig: B. G. Teubner.].

Heggarty, Paul

2005 Enigmas en el origen de las lenguas andinas. Revista Andina 40: 9-80.

Helberg Chavez, Heinrich A.

1984 Skizze einer Grammatik des Amarakaeri. Ph.D. dissertation, University of

Tubingen.

Hervas y Panduro, Lorenzo

1784-1787 Idea dell' universo: che contiene la storia della vita dell' uomo, elementi cosmografici, viaggio estatico al mondo planetario e storia della terra. Volumes

17-21. Cesena: Biasini.

Hervas y Panduro, Lorenzo

1800-1805 Catalogo de las lenguas de las naciones conocidas, y numeracion, division, y clases de estas segun la diversidad de sus idiomas y dialectos. Volume 1. Lenguas y naciones americanas. Madrid: Imprenta de la Administración de Real Arbitrio de Beneficiencia.

Hintz, Diane M. 
2007 Past tense forms and their functions in South Conchucos Quechua: Time, evidentiality, discourse structure, and affect. Ph.D. dissertation, University of California, Santa Barbara.

Hintz, Daniel J.

2008 Aspect and aspectual interfaces in South Conchucos Quechua: The emergence of grammatical systems. Ph.D. dissertation, University of California, Santa Barbara.

Hoff, Berend Jacob 1968 The Carib Language. The Hague: Martinus Nijhoff.

\section{camp_001.pod 42}

\section{7-10-06 13:07:39 -mu- mu}

\section{Willem F. H. Adelaar}

Hornberger, Nancy $\mathrm{H}$.

1998 Bilingual Education and Language Maintenance: A southern Peruvian case.

Dordrecht, Providence: Foris.

Hovdhaugen, Even

2005 Mochica. Munich: LINCOM Europa.

Howard, Rosaleen

1995 "Pachamama is a Spanish word": Linguistic tension between Aymara, Quechua and Spanish in Northern Potosi (Bolivia). Anthropological Linguistics 37

(2): 141-168.

Howard, Rosaleen

2007 Por los linderos de la lengua: ideologias linguisticas en los Andes. Lima: Pontificia Universidad Catolica del Peru, Instituto de Estudios Peruanos, Instituto Frances de Estudios Andinos.

Ibarra Grasso, Dick

1958 Lenguas indigenas americanas. Buenos Aires: Editorial Nova.

Imbelloni, Jose (ed.)

1926 La esfinge indiana: antiguos y nuevos aspectos de los origenes americanos.

Buenos Aires: El Ateneo.

Itier, Cesar

1991 Lengua general y comunicacion escrita: cinco cartas en quechua de Cotahuasi -

1616. Revista Andina 9 (1): 65-107.

Jahn, Alfredo

1927 Los aborigenes del Occidente de Venezuela: su historia, etnografia y afinidades

linguisticas. Caracas: El Comercio. (2nd edition, Caracas: Monte Avila

[1972].)

Jensen, Cheryl 
1999 Tupi-Guarani. In: R. M. W. Dixon and A. Y. Aikhenvald (eds.), The Amazonian

Languages, 125-63. Cambridge: Cambridge University Press.

Jijon y Caamano, Jacinto

1940-1945 El Ecuador interandino y occidental antes de la conquista castellana.

Quito: Editorial Ecuatoriana. (Also published by Abya-Yala, Quito [1998].)

Kann, Peter

1989 Die ethnographischen Aufzeichnungen in den wiederentdeckten Wortlisten

von Johann Natterer, wahrend seiner Brasilienreise zwischen 1817-35. Archiv

fur Volkerkunde 43: 101-146.

Kaufman, Terrence S.

1990 Language history in South America: What we know and how to know more. In:

D. L. Payne (ed.), Amazonian Linguistics: Studies in Lowland South American

Languages, 13-73. Austin: University of Texas Press.

Kaufman, Terrence S.

1994 The native languages of South America. In: Christopher Moseley and

R. E. Asher (eds.), Atlas of the World's languages, 46-76. London: Routledge.

Key, Mary Ritchie

1979 The Grouping of South American Indian Languages. Tubingen: Gunter Narr.

Klein, Harriet E. Manelis

1978 Una gramatica de la lengua toba: morfologia verbal y nominal. Montevideo:

Facultad de Humanidades y Ciencias, Universidad de la Republica.

\section{camp_001.pod 43}

\section{7-10-06 13:07:39 -mu- mu}

Historical overview 43

Klein, Harriet E. Manelis and Louisa R. Stark (eds.)

1985 South American Indian Languages: Retrospect and Prospect. Austin: University

of Texas Press.

Koch-Grunberg, Theodor

1909-1910 Zwei Jahre unter den Indianern: Reisen in Nordwest-Brasilien 1903-1905.

Berlin: Ernst Wasmuth.

Koch-Grunberg, Theodor

1913 Abschluß meiner Reise durch Nordostbrasilien zum Orinoco, mit Berucksichtigung

der von mir besuchten Indianerstamme. Zeitschrift fur Ethnologie 45:

448-474.

Koch-Grunberg, Theodor

1917 Von Roraima zum Orinoco: Ergebnisse einer Reise in Nordbrasilien und Venezuela in den Jahren 1911-13. Volume 1: Schilderung der Reise. Berlin: Reimer.

Koch-Grunberg, Theodor 
1928 Von Roraima zum Orinoco: Ergebnisse einer Reise in Nordbrasilien und Venezuela

in den Jahren 1911-13. Volume 4: Sprachen. Stuttgart: Strecker und

Schroder.

Komissarov, Boris

1994 Expedicao Langsdorff: Acervo e fontes historicas. Sao Paulo: Editora da Universidade

Estadual Paulista.

Krivoshein de Canese, Natalia

1983 Gramatica de la lengua guarani. Asuncion: Coleccion Nemit y.

Lafone Quevedo, Samuel A.

1893 Lenguas argentinas. Biblioteca Linguistica del Museo de La Plata. Volume 4.

La Plata. (Second edition published Buenos Aires: P.E. Coni [1896].)

Lafone Quevedo, Samuel A.

1895 Lenguas argentinas: Grupo mataco-mataguayo del Chaco, dialecto Nocten.

Boletin del Instituto Geografico Argentino 16: 343-389.

Lafone Quevedo, Samuel A.

1896 Grupo mataco-mataguayo del Chaco, dialecto Vejoz. Boletin del Instituto Geografico Argentino 17: 121-176.

Lafone Quevedo, Samuel A.

1927 Tesoro de Catamarquenismos. Buenos Aires: Casa Editora "Coni”.

Landaburu, Jon

1979 La langue des Andoke (Amazonie colombienne). Paris: SELAF.

Landaburu, Jon (ed.)

1996-1999 Documentos sobre lenguas aborigenes de Colombia del archivo de Paul

Rivet. Santafe de Bogota: Ediciones Uniandes.

Lapenda, Geraldo

1968 Estrutura da lingua iate. Recife: Universidade Federal de Pernambuco. (2nd

edition [2005].)

Lastra, Yolanda

1968 Cochabamba Quechua Syntax. The Hague / Paris: Mouton.

Launey, Michel

2003 Awna parikwaki: Introduction a la langue palikur de Guyane et de I'Amapa.

Paris: IRD Editions.

\section{camp_001.pod 44}

\section{7-10-06 13:07:39 -mu- mu}

\section{Willem F. H. Adelaar}

Lefebvre, Claire and Pieter C. Muysken

1988 Mixed Categories: Nominalizations in Quechua. Dordrecht: Kluwer.

Lehmann, Walter 
ms 1929 Vocabulario de la lengua uro. Berlin: Ibero-amerikanisches Institut Preussischer Kulturbesitz.

Lehmann-Nitsche, Robert

1913 El grupo linguistico Tshon de los territorios magallanicos. Revista del Museo

de la Plata 22: 217-276.

Lenz, Roberto

1895-1897 Estudios araucanos: materiales para el estudio de la lengua, la literatura

y las costumbres de los indios mapuches o araucanos. Santiago: Imprenta Cervantes.

First published in Volumes 90-91, 93-94 and 97-98 of the Anales de la

Universidad de Chile.

Lenz, Roberto

1905-1910 Los elementos indios del castellano de Chile: Estudio linguistico y etnologico.

Diccionario etimologico de las voces chilenas derivadas de lenguas

indigenas americanas. Annex to Anales de la Universidad de Chile. Santiago:

Imprenta Cervantes.

Lizot, Jacques

1970 Dictionnaire yanomami-francais. Paris: Laboratoire d'Anthropologie sociale

du College de France.

Lizot, Jacques

1975 Diccionario yanomami-espanol. Caracas: Universidad Central de Venezuela,

Facultad de Ciencias Economicas y Sociales.

Loukotka,C estmir

1968 Classification of South American Indian Languages. Edited by J. Wilbert. Los

Angeles: UCLA, Latin American Center.

Lucena Salmoral, Manuel

1967-1970 Gramatica chibcha del siglo XVII. Revista Colombiana de Antropologia 13

(1967): 31-90; 14 (1970): 203-220.

Lugo, Bernardo de

1978 Gramatica de la lengua general del Nuevo Reyno, Ilamada mosca. Madrid:

Ediciones de Cultura Hispanica. First published Madrid: Bernardino de Guzman

[1619].

Machoni de Cerdena, Antonio

1877 Arte y vocabulario de la lengua lule y tonocote. Buenos Aires: P. E. Coni. First

published Madrid: Herederos de Garcia Infanzon [1732].

Maccioni, Antonio

2008 Arte y vocabulario de la lengua lule y tonocote. Edited by R. Badini,

T. Deonette and S. Pineider. Cagliari: CUEC and Centro di Studi Filologici

Sardi.

Mackert, Michael 
1999 Horatio Hale's grammatical sketches of languages of the American Northwest

Coast: the case of Tsihaili-Selish. In: E. Nowak (ed.), Languages Different

in All their Sounds: Descriptive Approaches to Indigenous Languages of the Americas 1500 to 1850, 155-173. Munster: Nodus.

\section{camp_001.pod 45}

\section{7-10-06 13:07:39 -mu- mu}

Historical overview 45

Mamiani, Lodovico V.

1877 Arte de grammatica da lingua brasilica da nacao Kiriri. Rio de Janeiro: Bibliotheca Nacional do Rio de Janeiro. First published Lisbon: Miguel Deslandes [1699].

Mannheim, Bruce

1982 Person, number and inclusivity in two Andean languages. Acta Linguistica

Hafniensa 17 (2): 139-156. Copenhague: Reitzel.

Mannheim, Bruce

1991 The Language of the Inka since the European Invasion. Austin: University of Texas Press.

Markham, Clements R.

1864 Contributions towards a Grammar and a Dictionary of Quichua, the Language of the Incas of Peru. London: Trubner \& Co.

Markham, Clements R.

1871 Ollanta, an Ancient Ynca Drama. London: Trubner \& Co.

Marquez Miranda, Fernando

1943 Los textos millcayac del P. Luis de Valdivia con un vocabulario Espanol-

Allentiac-Millcayac. Revista del Museo de La Plata, NS, 2, Seccion de Antropologia

12: $61-223$.

Marr, Tim

1999 Neither the State nor the Grass Roots: Language Maintenance and the Discourse of the Academia Mayor de la Lengua Quechua. International Journal of

Bilingual Education and Bilingualism 2 (3): 181-197.

Martinez Companon, Baltasar Jaime

1985 Trujillo del Peru en el siglo XVIII, Volume 2. Madrid: Ediciones Cultura

Hispanica. First published [1782-1790].

Martins, Valteir

2005 Reconstrucao fonologica do Protomaku Oriental. Utrecht: Netherlands Graduate School of Linguistics (LOT).

Martius, Karl Friedrich Philipp von

1867 Beitrage zur Ethnographie und Sprachenkunde Amerikas, zumal Brasiliens. 
Leipzig: Friedrich Fleischer.

Mason, John Aldon

1950 The languages of South American Indians. In: J. H. Steward (ed.), Handbook

of South American Indians. Vol. 6: Physical Anthropology, Linguistics and

Cultural Geography of South American Indians, 157-317. Washington DC:

Smithsonian Institution.

Mata, Pedro de la

2007 Arte de la Lengua Cholona. Edited by Astrid Alexander-Bakkerus. Madrid:

Iberoamericana. Frankfurt am Main: Vervuert. First published [1748].

Mattei-Muller, Marie-Claude

1994 Diccionario ilustrado Panare-Espanol, Espanol-Panare. Caracas: Graficas

Armitano, Comision Nacional Quinto Centenario.

Matteson, Esther

1965 The Piro (Arawakan) Language. Berkeley: University of California Press.

Matteson, Esther

1967 Bolivian Indian Grammars. Norman: University of Oklahoma, Summer Institute of Linguistics.

\section{camp_001.pod 46}

\section{7-10-06 13:07:39 -mu- mu}

46 Willem F. H. Adelaar

McQuown, Norman A.

1955 The indigenous languages of Latin America. American Anthropologist NS 57:

501-570.

Meillet, Antoine and Marcel Cohen (eds.)

1952 Les langues du monde. Paris: Centre National de la Recherche Scientifique.

Meira, Sergio

1999 A grammar of Tiriyo. Ph.D. dissertation, Rice University, Houston.

Meira, Sergio

2000 A Reconstruction of Proto-Taranoan: Phonology and Morphology. Munich:

LINCOM Europa.

Melia, Bartomeu

1992 La lengua guarani del Paraguay. Madrid: Editorial MAPFRE.

Messineo, Cristina

2003 Lengua toba (guaycuru): aspectos gramaticales y discursivos. Munich: LINCOM

Europa.

Michael, Lev David

2008 Nanti evidential practice: Language, knowledge, and social action in an Amazonian

Society. Ph.D. dissertation, University of Texas, Austin. 
Middendorf, Ernst W.

1890-1892 Die einheimischen Sprachen Perus. Leipzig: Brockhaus.

Migliazza, Ernesto C.

1972 Yanomama grammar and intelligibility. Ph.D. dissertation, Indiana Un iversity,

Bloomington.

Migliazza, Ernesto C. and Lyle Campbell

1988 Panorama general de las lenguas indigenas en America. Caracas: Academia

Nacional de la Historia de Venezuela.

Miranda Esquerre, Luis (ed.)

2000 Actas I Congreso de Lenguas Indigenas de Sudamerica (Lima, August 1999).

Lima: Universidad Ricardo Palma, Facultad de Lenguas Modernas.

Mitre, Bartolome

1909-1910 Museo Mitre: Catalogo razonado de la seccion Lenguas Americanas. Buenos

Aires: Coni Hermanos.

Moesbach, Ernesto W. de

1930 Vida y costumbres de los indigenas araucanos en la segunda mitad del siglo

$X I X$, presentadas en la autobiografia del indigena Pascual Cona. Santiago de

Chile: Imprenta Cervantes

Moesbach, Ernesto W. de

1963 Idioma mapuche. Padre Las Casas: Editorial "San Francisco".

Montoya, Antonio Ruiz de

1876 Tesoro de la lengua guarani. Leipzig: J. Platzmann. First published Madrid:

Juan Sanchez [1639].

Montoya, Antonio Ruiz de

1994 Arte y bocabulario de la lengua guarani. Madrid: Ediciones de Cultura

Hispanica. First published Madrid: Juan Sanchez [1640].

Mortensen, Charles A.

1999 A Reference Grammar of the Northern Embera Languages. Dallas: SIL International and the University of Texas at Arlington.

\section{camp_001.pod 47}

\section{7-10-06 13:07:39 -mu- mu}

Historical overview 47

Moseley, Christopher and R. E. Asher (eds.)

1994 Atlas of the World's languages. London: Routledge.

Moseley, Christopher (ed.)

2009 Interactive Atlas of the World' s Languages in Danger. Online version http:// www.unesco.org/culture/languages-atlas/en/atlasmap.html [accessed 28 June

2011]. Paris: UNESCO. 
Moseley, Christopher (ed.)

2010 Atlas of the World's Languages in Danger. Paris: UNESCO.

Mosonyi, Esteban Emilio

1966 Morfologia del verbo yaruro: estudio de los sufijos personales. Caracas: Universidad

Central de Venezuela.

Mosonyi, Esteban Emilio and Jorge Carlos Mosonyi

2000 Manual de lenguas indigenas de Venezuela. Caracas: Fundacion Bigott.

Muysken, Pieter C.

1977 Syntactic Developments in the Verb Phrase of Ecuadorian Quechua. Lisse:

Peter de Ridder.

Muysken, Pieter C.

1979 La mezcla de quechua y castellano. El caso de la "media lengua" en el Ecuador.

LEXIS 3 (1): 41-56.

Muysken, Pieter C.

1997 Callahuaya. In: S. G. Thomason (ed.), Contact Languages: A Wider Perspective, 427-447. Amsterdam/Philadelphia: John Benjamins.

Najlis, Elena L.

1973 Lengua selknam. Buenos Aires: Universidad del Salvador.

Nantes, Bernard de

1896 Katecismo indico da lingua Kariris. Leipzig: Teubner. First published Lisbon:

Valentim da Costa [1709].

Nardi, Ricardo L. J.

2002 Introduccion al quichua santiagueno. Edited by L. I. Albarracin, M. C. Tebes

and J. R. Alderetes. Tucuman: Asociacion de investigadores en lengua quechua.

Buenos Aires: Editorial Dunken.

Nebrija, Elio Antonio de

1991 Introductiones Latinae. Salamanca: University of Salamanca. First published [1481].

Nebrija, Elio Antonio de

1980 Gramatica de la lengua castellana. Madrid: Antonio Quilis, Ed. Nacional.

First published [1492].

Nida, Eugene A.

1943 Morphology: The Descriptive Analysis of Words. Glendale, CA: Summer Institute of Linguistics.

Nimuendaju Unckel, Curt

1914 Die Sagen von der Erschaffung und Vernichtung der Welt als Grundlagen der

Religion der Apapokuva-Guarani. Zeitschrift fur Ethnologie 46: 284-403.

Nimuendaju Unckel, Curt

1981 Mapa etno-historico do Brasil e regioes adjacentes. Rio de Janeiro: Fundacao 
Instituto Brasileiro de Geografia e Estatistica and Fundacao Nacional Pro-

Memoria. First published Rio de Janeiro: Museu Nacional [1944].

\section{camp_001.pod 48}

\section{7-10-06 13:07:39 -mu- mu}

48 Willem F. H. Adelaar

Nordenskiold, Erland

1924 The Ethnography of South America seen from Mojos in Bolivia. Goteborg:

Elanders Boktryckeri.

Nowak, Elke

1999 Languages Different in All their Sounds: Descriptive Approaches to Indigenous

Languages of the Americas 1500 to 1850. Munster: Nodus.

Olawsky, Knut J.

2006 A Grammar of Urarina. Berlin/New York: Mouton de Gruyter.

Olza Zubiri, Jesus and Miguel Angel Jusayu

1978 Gramatica de la lengua guajira. Caracas: Universidad Catolica Andres Bello,

Ministerio de Educacion.

Oramas, Luis R.

1916 Materiales para el estudio de los dialectos Ayaman, Gayon, Jirajara, Ajagua.

Caracas: El Comercio.

Orbigny, Alcide Dessalines d'

1839 L' homme americain (de I'Amerique meridionale), considere sous ses rapports

physiologiques et moraux. Paris: Pitois-Levrault. Strasbourg: F.G. Levrault.

Ore, Luis Jeronimo de

1607 Rituale seu Manuale Peruanum. Naples: Giacomo Carlino and Costantino

Vitale.

Ortiz, Sergio Elias

1965 Lenguas y dialectos indigenas de Colombia. In: L. Duque Gomez (ed.), Historia

extensa de Colombia, vol. 1: Prehistoria. Academia Colombiana de Historia.

Bogota: Ediciones Lerner.

Ostler, Nicholas

1994 Syntactic typology of Muisca - a sketch. In: P. Cole, Gabriella Hermon and

Mario Daniel Martin (eds.), Language in the Andes, 205-230. Newark: University

of Delaware, Latin American Studies Program.

Ostler, Nicholas

2000 The development of transitivity in the Chibchan languages of Colombia. In:

J. C. Smith and D. Bentley (eds.), Historical Linguistics 1995, Volume 1: General

Issues and Non-Germanic Languages, 279-93. Amsterdam, Philadelphia:

John Benjamins. 
Ostler, Nicholas

2005 Empires of the Word: A Language History of the World. New York: HarperCollins.

Overall, Simon E.

2007 A grammar of Aguaruna. Ph.D. dissertation, La Trobe University, Victoria,

Australia.

Pacheco, Frantome B.

2001 Morfossintaxe do verbo ikpeng. Ph. D. dissertation, University of Campinas.

Pallas, P. Simon

1977-1978 Linguarum totius orbis vocabularia comparativa. Edited by H. Haarmann.

Hamburg: H. Buske. First published Saint Petersburg: K. Schnoor [1786-1789].

Park, Marinell, Nancy Weber and Victor Cenepo Sangama

1976 Diccionario quechua San Martin. Lima: Ministerio de Educacion, Instituto de

Estudios Peruanos.

\section{camp_001.pod 49}

\section{7-10-06 13:07:39 -mu- mu}

Historical overview 49

Parker, Gary John

1963 La clasificacion genetica de los dialectos quechuas. Revista del Museo Nacional

32: 241-252.

Parker, Gary John

1969 Ayacucho Quechua Grammar and Dictionary. The Hague / Paris: Mouton.

Parker, Gary John

1976 Gramatica quechua Ancash-Huailas. Lima: Ministerio de Educacion, Instituto

de Estudios Peruanos.

Parker, Gary J. and Amancio Chavez

1976 Diccionario quechua Ancash-Huailas. Lima: Ministerio de Educacion, Instituto

de Estudios Peruanos.

Patte, Marie-France

1989 Estudio descriptivo de la lengua Anun (o 'Paraujano'). San Cristobal: Universidad Catolica del Tachira.

Payne, Doris L. (ed.)

1990 Amazonian Linguistics: Studies in Lowland South American Languages. Austin:

University of Texas Press.

Payne, David L.

1991 A classification of Maipuran (Arawakan) languages based on shared lexical

retentions. In: D. C. Derbyshire and G. K. Pullum (eds.), Handbook of Amazonian

Languages, Volume 3, 353-499. Berlin/New York: Mouton de Gruyter.

Paz y Mino, Luis T. 
1936-1937 Contribucion al estudio de las lenguas indigenas del Ecuador. Boletin de la Academia Nacional de Historia 14: 40-54; 15: 9-41.

Paz y Mino, Luis T.

1940-1942 Lenguas indigenas del Ecuador. Boletin de la Academia Nacional de Historia 20 (56): 161-178 (La lengua pasto); 21 (57): 28-52 (La lengua kara); 21

(58): 145-170 (La kito o panzaleo); 22 (59): 42-74 (La lengua puruguay).

Paz y Mino, Luis T.

1961a Las agrupaciones y lenguas indigenas del Ecuador. Boletin de la Academia

Nacional de Historia 43 (97): 5-16.

Paz y Mino, Luis T.

1961b Lenguas indigenas del Ecuador: la lengua kanar. Boletin de la Academia Nacional

de Historia 43: 193-229.

Pike, Kenneth L.

1943 Tone Languages: The Nature of Tonemic Systems with a Technique for the

Analysis of their Significant Pitch Contrasts. Ann Arbor: University of Michigan

Press.

Pike, Kenneth L.

1947 Phonemics: A Technique for Reducing Languages to Writing. Ann Arbor: University

of Michigan Press.

Porterie-Gutierrez, Liliane

1988 Etude linguistique de 1'aymara septentrional (Perou-Bolivie). These Amerindia.

Paris: A.E.A.

Poser, William J.

1992 The Salinan and Yurumangui data in Language in the Americas. International

Journal of American Linguistics 58 (2): 202-229.

\section{camp_001.pod 50}

\section{7-10-06 13:07:39 -mu- mu}

50 Willem F. H. Adelaar

Pottier, Bernard (ed.)

1983 America Latina en sus lenguas indigenas. Caracas: UNESCO and Monte

Avila.

Pozzi-Escot, Ines

1998 El multilinguismo en el Peru. Cuzco: Centro "Bartolome de Las Casas".

Queixalos, Francois

1998 Nom, verbe et predicat en sikuani (Colombie). Paris: SELAF and Editions

Peeters.

Queixalos, Francois

2000 Syntaxe sikuani (Colombie). Paris: SELAF and Editions Peeters. 
Queixalos, Francois and Odile Renault-Lescure (eds.)

2000 As linguas amazonicas hoje. Sao Paulo: Institut de Recherche pour le Developpement, Instituto Socioambiental and Museu Paraense Emilio Goeldi.

Quesada Castillo, Felix

1976a Gramatica quechua Cajamarca-Canaris. Lima: Ministerio de Educacion, Instituto de Estudios Peruanos.

Quesada Castillo, Felix

1976b Diccionario quechua Cajamarca-Canaris. Lima: Ministerio de Educacion, Instituto de Estudios Peruanos.

Quesada Pacheco, Miguel Angel

1991 El vocabulario mosco de 1612. Estudios de linguistica chibcha 10: 29-99.

Ramirez, Henri

1994 Le parler yanomami des Xamatauteri. Ph.D. dissertation, Universite de

Provence, Aix-en-Provence.

Ramirez, Henri

1997 A Fala Tukano dos Ye’ pa-Masa. Tomo 1: Gramatica. Manaus: Inspetoria

Salesiana Missionaria da Amazonia, CEDEM.

Ramirez, Henri

2001 Linguas Arawak da Amazonia Setentrional: comparacao e Descricao. Manaus:

Editora da Universidade do Amazonas.

Reis Rodrigues, Carmen Lucia

1995 Etude morphosyntaxique de la langue chipaya (Bresil). Ph.D. dissertation, Universite Paris VII.

Ribeiro, Eduardo Rivail

2002 O marcador de posse alienavel em Kariri: Um morfema Macro-Je revisitado.

LIAMES 2: 31-48.

Ribeiro, Eduardo Rivail

2004 Prefixos relacionais em Je e Karaja: um estudo historico-comparativo.

LIAMES 4: 91-101.

Ribeiro, Eduardo Rivail and Hein van der Voort

2010 Nimuendaju was right: The inclusion of the Jabuti language family in

the Macro-Je stock. International Journal of American Linguistics 76 (4): 517-

583.

Ricardo, Antonio (ed.)

1985 Doctrina Christiana y catecismo para instruccion de los indios. Madrid: Consejo Superior de Investigaciones Cientificas. First published [1584].

\section{camp_001.pod 51}

\section{7-10-06 13:07:39 -mu- mu}


Historical overview 51

Ringmacher, Manfred and Ute Tintemann (eds.)

2011 Wilhelm von Humboldt Sudamerikanische Grammatiken. (Wilhelm-von-Humboldt

Schiften zur Sprachwissenschaft, dritte Abteilung: Amerikanische

Sprachen, Band 5.) Paderborn: Schoningh.

Rivarola, Jose Luis

1990 La formacion linguistica de Hispanoamerica. Lima: Fondo Editorial de la Universidad Catolica del Peru.

Rivet, Paul

1925 Les Australiens en Amerique. Bulletin de la Societe Linguistique de Paris 26:

23-63.

Rivet, Paul

1927 La famille linguistique timote. International Journal of American Linguistics 4

(2-4): 137-167.

Rivet, Paul

1942 Un dialecte hoka colombien: le yurumangi. Journal de la Societe des Americanistes

de Paris 34: 1-59.

Rivet, Paul andC` estmir Loukotka

1952 Langues de l'Amerique du Sud et des Antilles. In: Antoine Meillet and Marcel

Cohen (eds.), Les langues du monde, 1099-1160. Paris: Centre National de la

Recherche Scientifique.

Rivet, Paul and Georges de Crequi-Montfort

1951-1956 Bibliographie des langues aymara et kic ua. Paris: Universite de Paris, Institut d'Ethnologie.

Robins, Robert H. and Eugenius M. Uhlenbeck (eds.)

1991 Endangered Languages. Oxford / New York: Berg.

Rodrigues, Aryon Dall'Igna

1985 Evidnece for Tupi-Carib relationships. In: H.E.M. Klein and L.R. Stark (eds),

South American Indian Languages: Retrospect and Prospect, 371-404. Austin:

University of Texas Press.

Rodrigues, Aryon Dall'Igna

1986 Linguas brasileiras. Sao Paulo: Edicoes Loyola.

Rodrigues, Aryon Dall'Igna

1999 Macro-Je. In: R. M. W. Dixon and A. Y. Aikhenvald (eds.), The Amazonian

Languages. Cambridge: Cambridge University Press.

Rodrigues, Aryon Dall'Igna

2000 "Ge-Pano-Carib" x "Je-Tupi-Karib"; sobre relaciones linguisticas prehistoricas

en sudamerica'. In: L. Miranda Esquerre (ed.), Actas I Congreso de Lenguas

Indigenas de Sudamerica (Lima, August 1999), Volume 1, 95-104. Lima: 
Universidad Ricardo Palma, Facultad de Lenguas Modernas.

Rodrigues, Aryon Dall'Igna

2004 Sobre a possivel origem da diferenca fonetica entre a fala masculina e a feminina em Karaja. LIAMES 4: 115-121.

Rodrigues, Aryon Dall'Igna and Wolf Dietrich

1997 On the linguistic relationship between Mawe and Tupi-Guarani. Diachronica

14: 265-305.

Rojas Curieux, Tulio

1998 La lengua paez: una vision de su gramatica. Santafe de Bogota: Ministerio de Cultura.

\section{camp_001.pod 52}

\section{7-10-06 13:07:39 -mu- mu}

52 Willem F. H. Adelaar

Romero-Figueroa, Andres

1997 A Reference Grammar of Warao. Munich: LINCOM Europa.

Rondon, Candido Mariano da Silva and Joao Barbosa de Faria

1948 Glossario Geral das tribos silvicolas de Mato-Grosso e outras da Amazonia e do Norte do Brasi 1. Volume 1. Publicacao n. 76 da Comissao Rondon. Rio de Janeiro: Imprensa Nacional.

Rose, Francoise

2003 Grammaire de l'emrillon teko, une langue tupi-guarani de Guyane francaise.

Louvain: Peeters.

Sakel, Jeanette

2004 A Grammar of Moseten. Berlin/New York: Mouton de Gruyter.

Salas, Adalberto

1992a El mapuche o araucano: fonologia, gramatica y antologia de cuentos. Madrid:

Editorial MAPFRE.

Salas, Adalberto

1992b Linguistica mapuche. Revista Andina 10 (2): 473-537. Cuzco: Centro "Bartolome

de Las Casas".

Salas, Jose Antonio

2002 Diccionario Mochica-Castellano Castellano-Mochica. Lima: Universidad de

San Martin de Porres, Escuela Profesional de Turismo y Hoteleria.

Sandalo, Maria Filomena

1995 A grammar of Kadiweu. Ph.D. dissertation, University of Pittsburgh.

Santo Tomas, Domingo de

1994a Grammatica o arte de la lengua general de los indios de los reynos del Peru.

Madrid: Ediciones de Cultura Hispanica and UNESCO. First published Valladolid: 
Francisco Fernandez de Cordova [1560].

Santo Tomas, Domingo de

1994b Lexicon o vocabulario de la lengua general del Peru. Madrid: Ediciones de

Cultura Hispanica and UNESCO. First published Valladolid: Francisco Fernandez

de Cordova [1560].

Schleicher, Charles Owen

1998 Comparative and internal reconstruction of the Tupi-Guarani language family.

Ph.D. dissertation, University of Wisconsin, Madison.

Schuller, Rudolph R.

1908 Vocabularios y nuevos materiales para el estudio de las lenguas Lican-antai

(Atacamenos) - Calchaqui. Santiago de Chile: Imprenta Cervantes,

Schumann, Theophilus Salomon

1882 Grammatik der arawakischen Sprache. In: J. Crevaux, P. Sagot and L. Adam

(eds.), Grammaires et vocabularies Roucouyenne, Arrouague, Piapoco et

d'autres langues de la region des Guyanes, 166-240 (Bibliotheque Linguistique

Americaine 8). Paris: Maisonneuve.

Seelwische, Jose

1975 Gramatica nivacle. Na Lhasinonash napi Nivacle. Asuncion: El Grafico SRL.

Seelwische, Jose

1980 Nivakle-Ihcliish Somto-Ihcliish. Diccionario Nivacle-Castellano. Mariscal

Estigarribia, Chaco, Paraguay: UCNSA.

\section{camp_001.pod 53}

\section{7-10-06 13:07:39 -mu- mu}

Historical overview 53

Seelwische, Jose

1990 Diccionario nivacle: nivacle-castellano castellano-nivacle. Asuncion:

CEADUC.

Seifart, Frank

2005 The structure and use of shape-based noun classes in Mirana (North West

Amazon). Ph.D. dissertation, Radboud University Nijmegen. MPI Series in

Psycholinguistics.

Seki, Lucy

2000 Gramatica do Kamaiura: Lingua Tupi-Guarani do Alto Xingu. Campinas: Editora do UNICAMP.

Seler, Eduard

1902 Gesammelte Abhandlungen zur altamerikanischen Sprach- und Alterthumskunde.

Volume 1. Berlin: Asher.

Sherzer, Joel 
1983 Kuna Ways of Speaking: An Ethnographic Perspective. Austin: University of

Texas Press.

Silva Juliao, Maria Risoleta

2005 Aspects morphosyntaxiques de l'anambe. Ph.D. dissertation, University of

Toulouse - Le Mirail.

Smeets, Ineke

2008 A Grammar of Mapuche. Berlin/New York: Mouton de Gruyter.

Sorensen, Arthur P.

1967 Multilingualism in the Northwest Amazon.' American Anthropologist 69:

670-684.

Soto Ruiz, Clodoaldo

1976a Gramatica quechua Ayacucho-Chanca. Lima: Ministerio de Educacion, Instituto de Estudios Peruanos.

Soto Ruiz, Clodoaldo

1976b Diccionario quechua Ayacucho-Chanca. Lima: Ministerio de Educacion, Instituto de Estudios Peruanos.

Sousa Cruz, Maria Odileiz

2005 Fonologia e Gramatica Ingariko (Ka'pon - Brasil). Ph. D. dissertation, Free

University of Amsterdam.

Stark, Louisa R.

1972 Machaj-Juyay: Secret language of the Callahuayas. Papers in Andean Linguistics

1 (2): 199-218.

Steinen, Karl von den

1892 Die Bakairi-Sprache. Leipzig: Koehlers Antiquarium.

Stenzel, Kristine

2004 A reference grammar of Wanano. Ph. D. dissertation, University of Colorado,

Boulder.

Steward, Julian Haynes (ed.)

1950 Handbook of South American Indians. Volume 6: Physical Anthropology, Linguistics

and Cultural Geography of South American Indians. Washington DC:

Smithsonian Institution.

Steward, Julian Haynes and Louis C. Faron

1959 Native Peoples of South America. New York/Toronto/London: McGraw-

Hill.

\section{camp_001.pod 54}

\section{7-10-06 13:07:39 -mu- mu}

54 Willem F. H. Adelaar

Storto, Luciana 
1999 Aspects of a Karitiana grammar. Ph. D. dissertation, MIT. Cambridge, Massachusetts.

Suarez, Jorge A.

1974 Classification of South American Indian languages. Encyclopaedia Britannica

(15th edition). Macropaedia 17: 105-112.

Suarez Roca, Jose Luis

1992 Linguistica misionera espanola. Oviedo: Pentalfa.

Sušnik, Branislava J.

1958 Eenclit appaiwa: Lengua-Maskoy. Estructura gramatical. Part 1. Boletin de la

Sociedad Cientifica del Paraguay y del Museo Andre Barbero etnografico e

historico natural. Volume 2, Etnolinguistica 2. Asuncion: Museo Etnografico

"Andres Barbero".

Sušnik, Branislava J.

1977 Lengua-Maskoy: su hablar, su pensar, su vivencia. (Lenguas chaquenas 4.)

Asuncion: Museo Etnografico "Andres Barbero".

Sušnik, Branislava J.

1986-1987 Los aborigenes del Paraguay. Volume 7 (1), Lenguas chaquenas. Asuncion:

Museo Etnografico "Andres Barbero".

Swadesh, Morris

1959 Mapas de clasificacion linguistica de Mexico y las Americas. (Cuadernos del Instituto de Historia, Serie Antropologica 8.) Mexico: Universidad Nacional

Autonoma de Mexico.

Swadesh, Morris

1962 Afinidades de las lenguas amerindias. In: Akten des 34. Amerikanistenkongresses (Vienna, July 1960), 729-38. Vienna: Fred Berger.

Tapia, Diego de

1723 Confessionario en lengua cumanagota, y de otras naciones de Indios de la Provincia de Cumana. Madrid: Pedro Fernandez.

Taunay, Alfredo d'Escragnolle

2000 Ierece a Guana. Edited by Sergio Medeiros. Sao Paulo: Editora lluminuras.

Tauste, Francisco de

1680 Arte y vocabulario de la lengua de los indios chaymas, cumanagotos, cores, parias y otros diversos de la provincia de Cumana o Nueva Andalucia. Madrid.

Imprenta de Bernardo Villa-Diego.

Tavares, Petronila

2005 A grammar of Wayana. Ph.D. dissertation, Rice University, Houston.

Taylor, Gerald

1975 Le parler quechua d' Olto, Amazonas (Perou). Paris: SELAF.

Taylor, Gerald

1982 Aspectos de la dialectologia quechua. Volume 1, Introduccion al quechua de 
Ferrenafe. Chantiers Amerindia. Paris: A.E.A.

Taylor, Gerald

1991 Introducao a lingua baniwa do Icana. Campinas: Editora da UNICAMP.

Telles, Stella Virginia

2002 Fonologia e gramatica Latunde-Lakonde. Ph. D. dissertation, Free University

of Amsterdam.

\section{camp_001.pod 55}

\section{7-10-06 13:07:39 -mu- mu}

Historical overview 55

Terraza, Jimena

2008 Gramatica del wichi: fonologia y morfosintaxis. Ph.D. dissertation, Universite du Quebec a Montreal, Montreal.

Tessmann, Gunter

1930 Die Indianer Nordost-Perus. Hamburg: Friedrichsen, de Gruyter. (Published in

Spanish as Los indigenas del Peru nororiental. Quito: Abya-Yala [1999].)

Thiesen, Wesley and David J. Weber

Forthcoming A grammar of Bora. Dallas: SIL International and the University of Texas at Arlington.

Torero Fernandez de Cordova, Alfredo A.

1964 Los dialectos quechuas. Anales Cientificos de la Universidad Agraria 2 (4):

$446-478$.

Torero Fernandez de Cordova, Alfredo A.

1974 El quechua y la historia social andina. Lima: Universidad Ricardo Palma.

Torero Fernandez de Cordova, Alfredo A.

2002 Idiomas de los Andes: linguistica e historia. Lima: Instituto Frances de Estudios

Andinos, Editorial Horizonte

Tovar, Antonio

1961 Catalogo de las lenguas de America del Sur. Buenos Aires: Editorial Sudamericana.

Tovar, Antonio

1980 Relatos y dialogos de los matacos. Madrid: Ediciones Cultura Hispanica del

Instituto de Cooperacion Iberoamericana.

Tovar, Antonio, and Larrucea de Tovar, Consuelo

1984 Catalogo de las lenguas de la America del Sur con clasificaciones, indicaciones tipologicas, bibliografia y mapas. Madrid: Editorial Gredos.

Triana y Antorveza, Humberto

1987 Las lenguas indigenas en la historia social del Nuevo Reino de Granada. Bogota: Instituto Caro y Cuervo.

Trillos Amaya, Maria 
1999 Damana. Munich/Newcastle: LINCOM Europa.

Tschudi, Johann Jakob von

1853 Die Kechua-Sprache. Vienna: Kaiserlich-konigliche Hof- und Staatsdruckerei.

Uhle, Max

1890 Verwandtschaften und Wanderungen der Tschibtscha. Acts of the 7 th International

Congress of Americanists (Berlin 1888): 466-89.

Uhle, Max

ms 1895 Grundzuge einer Uro-Grammatik und Uro Vokabular. Berlin: Ibero-amerikanisches

Institut Preussischer Kulturbesitz.

Uricoechea, Ezequiel

1871 Gramatica, vocabulario, catecismo i confesionario de la lengua chibcha. (Coleccion linguistica americana 1.) Paris: Maisonneuve. (Also published by

Krauss Reprint, Nendeln, Liechtenstein [1968].)

Valdivia, Luis de

1887 Arte y gramatica general de la lengua que corre en todo el Reyno de Chile, con un vocabulario y confesionario. Leipzig: Teubner. First published Lima: Francisco

del Canto [1606].

\section{camp_001.pod 56}

\section{7-10-06 13:07:39 -mu- mu}

\section{Willem F. H. Adelaar}

Valdivia, Luis de

1894 Doctrina Cristiana y catecismo con un confesionario: arte y vocabulario breves en lengua allentiac. Edited by J. T. Medina. Seville: Rasco. First published [1607].

Valenzuela, Pilar M.

2003 Transitivity in Shipibo-Konibo grammar. Ph.D. dissertation, University of

Oregon, Eugene.

Vellard, Jehan A.

1950-1951 Contribution a l'etude des indiens uru ou kot'suns. Travaux de l' Institut

Francais d'Etudes Andines 2: 51-88; 3: 3-39.

Vidal, Alejandra

2001 Pilaga grammar (Guaykuruan family, Argentina). Ph.D. dissertation, University

of Oregon, Eugene.

Viegas Barros, J. Pedro

2001 Evidencias del parentesco de las lenguas Lule y Vilela. Santa Fe (Argentina):

Gobierno de Santa Fe.

Viegas Barros, J. Pedro

2005 Voces en el viento. Raices linguisticas de la Patagonia. Buenos Aires: Mondragon 
Ediciones.

Vinas Urquiza, Maria T.

1974 Lengua mataca. Buenos Aires: Centro de Estudios Linguisticos, Universidad

de Buenos Aires.

Voort, Hein van der

2004 A Grammar of Kwaza. Berlin/New York: Mouton de Gruyter.

Weber, David John

1989 A Grammar of Huallaga (Huanuco) Quechua. Berkeley/Los Angeles/London:

University of California Press.

Weber, David J.

1994 Ortografia. Lecciones del quechua. Lima: Ministerio de Educacion, Instituto

Linguistico de Verano.

Wetzels, Leo (ed.)

1995 Estudos fonologicos das linguas indigenas brasileiras. Rio de Janeiro: Editora

UFRJ.

Wiesemann, Ursula

1972 Die phonologische und grammatische Struktur der Kaingang-Sprache. The

Hague: Mouton.

Wise, Mary Ruth

1976 Apuntes sobre la influencia inca entre los amuesha: factor que oscurece la clasificacion

de su idioma. Revista del Museo Nacional 42: 355-66.

Wurm, Stephen A. (ed.)

1996 Atlas of the World' s Languages in Danger of Disappearing. Paris: UNESCO;

Canberra: Pacific Linguistics. (Revised edition, Paris: UNESCO [2001].)

Yankievich de Mirievo, Theodor

1790-1791 Sravnitel' nyj slovar' vsex jazykov i narec 'ij po azbuc nomu porjadku raspoloz enny j. Saint Petersburg.

Zamponi, Raoul

2003a Betoi. Munich: LINCOM.

\section{camp_001.pod 57}

\section{7-10-06 13:07:39 -mu- mu}

Historical overview 57

Zamponi, Raoul

2003b Maipure. Munich: LINCOM.

Zariquiey Biondi, Roberto D.

2011-08-01 A grammar of Kashibo-Kakataibo. Ph.D. dissertation, La Trobe University,

Victoria, Australia.

Zavala, Silvio 
1977 . El castellano, lengua obligatoria? Mexico: Centro de Estudios de Historia de Mexico.

Zimmermann, Klaus (ed.)

1997 La descripcion de las lenguas amerindias en la epoca colonial. Madrid: Iberoamericana.

Frankfurt am Main: Vervuert.

Zuniga, Fernando

2000 Mapudungun. Munich: LINCOM Europa.

Zuniga Castillo, Madeleine and Alicia Carrasco de Moya

1978 Programa Experimental de Quinua (Informe de 1964-1968). (Centro de Investigacion

de Linguistica Aplicada, Documento 39.) Lima: Universidad Nacional

Mayor de San Marcos.

Zwartjes, Otto (ed.)

2000 Las gramaticas misioneras de tradicion hispanica (siglos XVI-XVII). Amsterdam/

Atlanta: Rodopi.

\section{camp_001.pod 58}

\section{7-10-06 13:07:39 -mu- mu}

58 Willem F. H. Adelaar 